NBER WORKING PAPER SERIES

\title{
EARNINGS QUALITY AND OWNERSHIP STRUCTURE: THE ROLE OF PRIVATE EQUITY SPONSORS
}

\author{
Sharon Katz \\ Working Paper 14085 \\ http://www.nber.org/papers/w14085 \\ NATIONAL BUREAU OF ECONOMIC RESEARCH \\ 1050 Massachusetts Avenue \\ Cambridge, MA 02138 \\ June 2008
}

This paper is based on my dissertation at Columbia University, which won the 2007 AAA Competitive Manuscript Award as well as the 2007 AAA Financial Accounting and Reporting Section, Best Dissertation Award. I would like to thank my committee members?Andrew Ang, Daniel Cohen, Bjorn Jorgensen (sponsor), Doron Nissim, and Stephen Penman (chair)?for their guidance and support. I would also like to thank the following for their helpful comments: Nerissa Brown, Fabrizio Ferri, Dan Givoly, Carla Hayn, Paul Healy, Yael Hochberg, Michael Kimbrough, Gregory Miller, Partha Mohanram, Edward Riedl, Joseph Weber, Yuan Zhang, and the participants in workshops at the U.S. Securities and Exchange Commission, the AAA 2006 annual meeting, Columbia University, Duke University, the EAA 2007 annual congress, Harvard University, Massachusetts Institute of Technology, NBER - New World of Private Equity Conference, Northwestern University, Penn State University, the University of California?Berkeley, the University of California?Los Angeles, the University of Chicago, the University of Michigan, the University of Notre Dame, and Yale. I thank Joseph Marren, my former colleague at the M\&A department of Citigroup Investment Banking, for his insightful feedback. I also want to thank my wife, Elissa Swift Katz, for her support during the process. I gratefully acknowledge financial support from Columbia Business School, the Deloitte Doctoral Fellowship, and Harvard Business School. All errors are mine. The views expressed herein are those of the author(s) and do not necessarily reflect the views of the National Bureau of Economic Research.

NBER working papers are circulated for discussion and comment purposes. They have not been peerreviewed or been subject to the review by the NBER Board of Directors that accompanies official NBER publications.

(C) 2008 by Sharon Katz. All rights reserved. Short sections of text, not to exceed two paragraphs, may be quoted without explicit permission provided that full credit, including $($ ) notice, is given to the source. 
Earnings Quality and Ownership Structure: The Role of Private Equity Sponsors

Sharon Katz

NBER Working Paper No. 14085

June 2008

JEL No. G0,G24,G3,M1,M41

\begin{abstract}
$\underline{\text { ABSTRACT }}$
This study explores how firms' ownership structures affect their earnings quality and long-term performance. Focusing on a unique sample of private firms for which there is financial data available in the years before and after their initial public offering (IPO), I differentiate between those that have private equity sponsorship (PE-backed firms) and those that do not (non-PE-backed firms). The findings indicate that PE-backed firms generally have higher earnings quality than those that do not have PE sponsorship, engage less in earnings management and report more conservatively both before and after the IPO. Further, PE-backed firms that are majority-owned by PE sponsors exhibit superior long-term stock price performance after they go public. These results stem from the professional ownership, tighter monitoring, and reputational considerations exhibited by PE sponsors.
\end{abstract}

Sharon Katz

Harvard University

Morgan Hall 383

Harvard Business School

Boston, MA 02163

skatz@hbs.edu 


\section{Earnings Quality and Ownership Structure: The Role of Private Equity Sponsors}

\section{INTRODUCTION}

Although private firms have a significant presence in the U.S. market, constituting $99 \%$ of companies, ${ }^{1}$ their accounting practices remain largely unknown due mainly to the lack of publicly available financial statements. ${ }^{2}$ Using a unique sample of firms with privately held equity and publicly held debt for which complete and standardized financial data is available, ${ }^{3}$ this study explores how the ownership structure of a firm affects its financial reporting practices, financial performance, and stock returns in the years preceding and following IPO. Two different ownership structures of pre-IPO firms are considered - those with private equity sponsorship (PE-backed firms) and those with no outside sponsorship (non-PE-backed firms). ${ }^{4}$

PE sponsors have become prominent in the U.S. capital markets, participating in more than one-third of IPOs and in more than one-quarter of the U.S. mergers during the past few years. The value of private equity buyouts in the United States surged to $\$ 220$ billion in 2006, and $\$ 438$ billion in private-equity deals were announced in $2007 .^{5}$ This rapid growth and globalization of the PE industry has raised demands for increased regulation and disclosure within the sector due to concerns regarding anticompetitive behavior, excessive tax benefits, and

\footnotetext{
${ }^{1}$ See AICPA web site: http://www.aicpa.org/download/news/2004/Discussion_Paper_5-10-04.pdf.

${ }^{2}$ Indeed, Hand (2005), who uses prospectus information to gain insight into private firms, emphasizes that he is "unaware of any other systematic, large-sample source of financial statement data for pre-IPO companies."

${ }^{3}$ Only scant data is available on privately held firms in the United States, with the exception of firms in regulated industries such as financial and insurance companies (Beatty and Harris 1998, Mikhail 1999, Beatty et al. 2002). Private firms with public debt are nevertheless subject to the same financial reporting regulations as public firms under sections 13 and 15(d) of the Securities Exchange Act of 1934. This sample includes such large and familiar firms as J. Crew, Sealy Corp., and UPS.

${ }^{4}$ PE-backed firms are majority- or minority-owned by PE sponsors, investment firms such as the Blackstone Group, Texas Pacific Group, and Kohlberg Kravis Roberts \& Co., which generally buy mature businesses via leveraged buyout (LBO) or management buyout (MBO) transactions and take them private. Non-PE-backed firms are defined in this study as firms that are majority owned by management and do not have PE-sponsorship.

${ }_{5}^{5}$ Investment Dealers' Digest, February 23, 2006; Economist.com, February 8, 2007; Forbes, December 10, 2007; and USA Today, January 29, 2008.
} 
stock manipulation. ${ }^{6}$ PE-backed IPOs (also known as reverse-LBOs), in particular, have recently been the subject of public scrutiny. ${ }^{7}$

Despite their economic importance and the management expertise they bring, little is known about the role PE sponsors play in their portfolio companies' accounting practices. Most prior research has focused on venture capital (VC) firms rather than PE sponsors. Although studies of the role of VC firms yield valuable (albeit mixed) insights into how ownership structure affects accounting practices, findings from such studies cannot be generalized to PE sponsors owing to significant institutional differences between VC firms and PE sponsors. ${ }^{8}$

Hence, this study sets out to test how PE sponsors' alleged opportunistic behavior (Degeorge and Zeckhauser 1993), on the one hand, combined with their tighter monitoring and reputational considerations (e.g., Cao and Lerner 2006), on the other, affect earnings management, conservatism, and post-IPO performance compared to non-PE-backed firms owned and controlled by their management teams. To accomplish this, I leverage a unique sample of 147 IPOs (1,070 firm-year observations) that occurred between 1980 and 2005, for which a longer time-series of pre-IPO financial statements is available than in a typical prospectus.

\footnotetext{
${ }^{6}$ The Wall Street Journal, October 10, 2006; The Wall Street Journal, January 29, 2007; BusinessWeek, April 26, 2007; Associated Press, July 11, 2007.

${ }^{7}$ Newspaper headlines such as "Private equity walks on water. But more of its new issues sink like a stone than you would think" refer to reverse LBOs that went sour, such as Refco, Inc. and Sealy Corporation, the stock price of which dropped 59\% in the 19 months following its IPO (Forbes, December 10, 2007).

${ }^{8}$ For example, unlike VC firms, which invest in early-stage, mostly not yet profitable firms and rarely use bank debt, PE sponsors generally buy mature, profitable businesses via leveraged buyout (LBO) or management buyout (MBO) transactions, finance the transactions with large portions of bank debt, and typically assume control of the board of directors, but are generally less likely than VC firms to assume operational control (for further discussion, see section II).
} 
I first compare the tendency of PE-backed and non-PE-backed firms to engage in earnings management in the period surrounding an IPO (five years before and five years after). I find that PE-backed firms engage in significantly less upward earnings management than nonPE-backed firms both pre- and post-IPO, consistent with tighter monitoring by, and the reputational considerations of, PE sponsors.

I also examine whether PE-backed and non-PE-backed firms differ with respect to timely loss recognition. Although all firm-year observations in my sample are subject to identical financial reporting regulations, the results suggest that PE-backed firms recognize losses in a timelier manner than non-PE-backed firms, especially in the pre-IPO period. This is consistent with the greater demand for timely information these firms face from both PE sponsor-owners and debt holders. Furthermore, PE sponsors that can better anticipate and prepare their portfolio firms for future IPOs (Gompers 1995, Kaplan and Strömberg 2003) are expected to report more conservatively due to public investors' anticipated demands.

Finally, I test whether post-IPO, long-term financial and stock-price performance are associated with characteristics of ownership status and PE sponsor size. This study documents that in the post-IPO period, majority ownership by a PE sponsor is associated with better longterm stock price performance, and minority ownership by a PE sponsor with worse long-term financial and stock price performance, than ownership by management, and that larger PE sponsor size is positively associated with better long-term financial and stock price performance when the firm goes public. These findings are consistent with the monitoring role of PE sponsors. Moreover, having PE sponsors with higher ownership stakes, especially larger PE sponsors with greater capital under management (as a reputation proxy), is expected to contribute to even tighter monitoring and, hence, better long-term performance. 
This paper contributes to the existing literature in several ways. First, the study furthers our understanding of how ownership concentration and structure affect financial reporting practices (e.g., Leuz et al. 2003, Haw et al. 2004, and Leuz 2006, among others). The present study focuses, in particular, on the role of PE sponsors, which has attracted little attention in the recent academic literature, mainly due to research design limitations imposed by lack of publicly available pre-IPO financial statements. The complete and standardized financial information available for my sample of PE-backed firms for a period of five years before the IPO enables me to overcome these limitations, and to address the accounting reporting differences between PEbacked and non-PE-backed firms.

Second, this paper contributes to the literature on earnings management in the context of IPOs in general (e.g., Aharony et al. 1993, Teoh et al. 1998, 1998a), and IPOs that are backed by private equity sponsors and VCs, in particular (Chou et al. 2006, Hochberg 2006, Morsfield and Tan 2006, Wongsunwai 2007). These studies have relied heavily on prospectus filings, which have been shown to be contaminated by optimistic bias, window dressing, and earnings manipulation (Ang and Brau 2002). ${ }^{9}$ Recent literature has raised further the concern that receipt of IPO proceeds during the year of IPO might inflate the earnings management measures reported in these studies (Ball and Shivakumar 2006b). I avoid retrospectively prepared prospectus financials in favor of audited $10 \mathrm{Ks}$ filed in real time, and am further able to rely on pre-IPO financials.

Third, this study also expands upon the growing literature on the post-IPO performance of U.S. PE-backed firms. This literature, which focuses mainly on the market performance of reverse-LBOs as compared to “ordinary" IPOs (DeGeorge and Zeckhauser 1993, Holthausen and

\footnotetext{
${ }^{9}$ According to paragraph 29 of Accounting Principles Board Opinion No. 20, companies filing publicly for the first time are permitted a restatement.
} 
Larcker 1996, and, more recently, Cao and Lerner 2006), documents better long-term performance by reverse-LBO firms. But other differences, beyond differences in ownership structure, can affect these findings. For example, reverse-LBOs are mature firms that return to the public market, whereas ordinary IPOs are more commonly much younger growth firms without a financial reporting history. That both the PE-backed and non-PE-backed firms in my sample are mature firms enables me to better focus on the effect of ownership structure. ${ }^{10}$

Finally, although private firms are important players in the U.S. market, ${ }^{11}$ their accounting practices remain largely unknown due mainly to the lack of publicly available financials. My unique sample of private firms with public debt, also examined by Givoly et al. (2007b), makes it possible to broaden our understanding of the reporting practices of U.S. private firms in a variety of industries and under different ownership structures. My findings on the effect of ownership structure are important to stakeholders such as banks, customers, employees, and suppliers that depend on the financial health of private firms.

The remainder of this paper is organized as follows. Section II discusses the motivation for and theory that underlies the hypotheses. Section III describes the data collection procedures and research design, section IV the sample descriptive statistics. Results are presented in section V. Section VI reports the results of a variety of robustness checks. Section VII concludes with a discussion and implications for future research.

\footnotetext{
${ }^{10}$ Chou et al. (2006) address the influence of ownership structure on abnormal market returns in the post-IPO period and conclude that, except for effects propagated through earnings management, acquirer status (PE sponsor versus management-owner) has little additional influence on post-issue price performance. Hence, whether ownership status influences post-IPO performance remains an empirical question.

${ }^{11}$ The 500 largest private firms together employed 4.4 million people and had revenues of $\$ 1.4$ trillion (Forbes, November 27, 2006). Beyond their ubiquity, the financial reporting of private firms is of particular interest. In June 2006, the AICPA and FASB agreed to create a joint committee to improve the financial reporting process for private firms.
} 


\section{MOTIVATION, THEORY, AND HYPOTHESES}

\section{Private Equity Sponsors}

The present study focuses on the role of PE sponsors, which has attracted little attention in the recent academic literature relative to the considerable attention devoted to the role of another type of private investor, VC firms.

The evidence to date regarding the effect of $\mathrm{VC}$ ownership structure on earnings quality is limited and mixed. Several recent VC studies document less upward earnings management by VC-backed IPOs (as measured by lower discretionary accruals) than is observed in non-VCbacked IPOs (Hochberg 2006, Morsfield and Tan 2006). Wongsunwai (2007) further finds that post-IPO firms backed by higher-quality VCs have lower discretionary accruals and lower likelihood of financial restatements. Other VC studies, however, document lower earnings quality in the presence of VCs. For example, Cohen and Langberg (2005) document that reported accounting earnings are less informative for VC-backed firms than for non-VC-backed firms, and Darrough and Rangan (2005) find VCs' share sales in the year of the IPO to be negatively associated with R\&D spending changes under some specifications, consistent with these VCs' incentive to increase reported earnings.

There are also important institutional differences between VC-backed and PE-backed IPOs that make it difficult to rely on the findings of the VC literature in the PE context. ${ }^{12}$ For example, unlike VCs, which invest in early-stage and mostly not yet profitable companies, PE sponsors generally buy mature, profitable businesses that had been subject to full financial disclosure before the IPO. The expected, much reduced information asymmetry between issuer and investors (Cai 2002) further limits opportunities for PE sponsors to manage earnings before

\footnotetext{
${ }^{12}$ Indeed, the VC literature actually excludes PE-backed firms from its analysis (e.g., Hochberg 2006).
} 
the IPO. ${ }^{13}$ On the other hand, PE sponsors hold their portfolio firms through LBO funds that have limited life spans of 10-12 years, and usually share around $20 \%$ of the upside gain via carried interest (in addition to management fees of about $2 \%$ of the assets under management). ${ }^{14}$ Hence, PE sponsors have a strong incentive to file for IPO before the funds mature, and further incentive to manage reported earnings upward if needed in order to maximize profits from their investments (Cao 2007). ${ }^{15}$

Indeed, the only U.S. study of which I am aware that addresses the influence of ownership structure (PE-backed versus non-PE-backed) on accounting practices, Chou et al. (2006), identifies significant upward earnings management (positive discretionary accruals) in the year of an IPO only in PE-backed firms. But the authors cannot conclude that PE sponsors' involvement in upward earnings management is greater than that of management-owners due to the small sample size. These findings, although statistically insignificant, are surprising in light of the results reported above in the VC literature. ${ }^{16}$ Whether ownership status influences pre-IPO earnings management thus remains an empirical question. The complete and standardized financial information available for my sample of PE-backed firms before the IPO lends deeper

\footnotetext{
${ }^{13}$ Although information asymmetry might be lower for my sample, the price effect of earnings management might be higher than in the case of "ordinary" IPOs and VC-backed firms, which, having little to no earnings history, have little or no earnings to manage (Chou et al. 2006).

${ }^{14}$ In contrast, VCs rarely charge up-front investment banking or management fees (Sahlman 1990).

${ }^{15}$ Additional differences between PE sponsors and VCs are documented in the literature. PE-backed firms tend to have large enterprise value and use bank debt; PE sponsors generally acquire mature, established companies and seek a majority stake; profit levels are crucial and technology considerations largely irrelevant; and PE managers typically come from an accounting, investment banking, or management consulting background. VC-backed firms, on the other hand, tend to have small enterprise value and rarely use bank debt; generally acquire young companies and start-ups and take only a minority stake; the portfolio firms, though mostly not profitable, are always developing or applying new technology; and VC managers have often been successful start-up entrepreneurs or possess specialized technology expertise (Hand 2005, Chou et al. 2006, Morsfield and Tan 2006, Fraser-Sampson 2007, Klein and Zur 2007). Furthermore, PE sponsors typically assume control of the board of directors, but are generally less likely than VCs to assume operational control, and PE sponsors' compensation is more highly sensitive to value creation (Sahlman 1990, Wright and Robbie 1998).

${ }^{16}$ I was able to replicate the results of Chou et al. (2006) for PE-backed firms in the year of IPO using the Jones (1991) cross sectional current accruals model. I also identify significant positive discretionary abnormal accruals in PE-backed firms; however, my results indicate that their involvement in upward earnings management during the IPO year is lower than that of management-owners (see the discussion in section V).
} 
insight into their reporting practices, and enables me to re-address the accounting reporting differences between PE-backed and non-PE-backed firms.

\section{Earnings Management}

The evidence to date regarding the effect of ownership structure (PE-backed versus nonPE-backed) on earnings management is limited and mixed.

On one hand, theory and empirical evidence support the prediction that the active monitoring associated with the presence of PE sponsors inhibits earnings management. PE sponsors are likely to play a role in restructuring management compensation, and can actively monitor and motivate management by virtue of their board membership (Gompers 1995, Lerner 1995, Cotter and Peck 2001, Renneboog and Simons 2005). Tighter monitoring, more sophisticated ownership, and board membership are, in turn, expected to be associated with less earnings management (e.g., Xie et al. 2003, Cornett et al. 2005, Wongsunwai 2007). The separation of management and control enhance the monitoring role of these PE-sponsors, as compared to non-PE-backed firms, which are both owned and controlled by their management teams and, hence, expected to manage earnings further at the expense of future owners. Furthermore, being repeat players in the LBO debt market as well as the IPO market, PE sponsors risk reputation loss if their LBOs or IPOs fail (Cotter and Peck 2001, Cao and Lerner 2006), which also can lead to less upward earnings management by PE-backed firms.

On the other hand, theory and empirical evidence support greater earnings management by PE-backed than by non-PE-backed firms, especially in the period surrounding an IPO. First, Degeorge and Zeckhauser (1993) suggest that PE-backed firms' decision to return to public listing is driven by opportunistic behavior and IPO timing. If PE-backed firms indeed go public 
because they have exhausted the benefits of the LBO ownership form or their profits are insufficient to cover their debt load, I would expect them to manage earnings upward to a greater extent than non-PE-backed firms. Second, managers who feel more compelled to meet the earnings goals of the sophisticated PE sponsors for whom they work might, at least in principle, have greater motivation to manage earnings (Cornett et al. 2005). Finally, prior literature also documents that differences in firms' ownership concentration can affect reporting incentives and earnings management. Because in a more concentrated ownership structure, large owners typically sit on the board and are often directly involved in firm management, communicating firm performance via financial statements becomes less important than earnings management intended to hide expropriation activities from outside investors (Leuz 2006). ${ }^{17}$ Given that firms that are majority owned by PE sponsors have higher ownership concentration than firms that are owned by management (see Table 4), I further expect them to have greater propensity to manage earnings.

Although it remains an empirical question whether PE-backed firms engage in more upward earnings management than non-PE-backed firms, my first hypothesis (stated in alternative form), consistent with the monitoring role of PE sponsors, is:

H1: Non-PE-backed firms engage in upward earnings management to a greater extent than do PE-backed firms.

\footnotetext{
${ }^{17}$ Indeed, both Leuz et al. (2003) and Haw et al. (2004) document a positive correlation between earnings management and ownership concentration, at least in firms with high levels of management ownership (Yeo et al. 2002).
} 


\section{Timely Loss Recognition (Conservatism)}

Prior literature identifies timely loss recognition as an important attribute of financial reporting quality (e.g., Basu 1997, Ball and Shivakumar 2005, Givoly et al. 2007a). ${ }^{18}$

I expect PE-backed firms to have more timely loss recognition than non-PE-backed firms because they face greater demand for timely information. First, Ball and Shivakumar (2006b) document that U.K. private firms begin to report more conservatively a few years before public listing in anticipation of expected post-IPO demands of public investors and the public market enforcement mechanism. Because PE sponsors can better anticipate and prepare their portfolio firms for future IPOs (Gompers 1995, Kaplan and Strömberg 2003), I expect PE-backed firms to report more conservatively in the pre-IPO period than non-PE-backed firms that cannot as easily anticipate the exit. Second, that PE-backed private firms tend to have significantly higher leverage than non-PE-backed private firms (see Table 2, Panel A) can lead debt holders to demand more timely loss recognition (Ball et al. 2005). Finally, Kaplan and Strömberg (2003) show that PE sponsors make control rights contingent on financial as well as non-financial measures, which can trigger a harsher financial reporting discipline than for firms owned by management and, hence, increase demand for higher-quality accounting information.

Alternative theory and empirical evidence support less timely loss recognition by PEbacked firms. Because, due to their higher ownership concentration (see Table 4), PE sponsorowners can more easily resolve any information asymmetry through "insider access" and thus have less need to rely on public disclosure, they have less incentive to incorporate economic losses into accounting income in a timely manner (for a discussion of "insider access," see Ball

\footnotetext{
${ }^{18}$ Basu (1997) defines conservatism as follows: "Accountants' tendency to require a higher degree of verification for recognizing good news than bad news in financial statements ... earnings reflect bad news more quickly than good news." Pre-IPO firms in my sample do not have stock prices. Therefore, following Ball and Shivakumar (2005), who compared private and public firms in the United Kingdom, I use a conservatism model that does not require stock prices (see the discussion in section III).
} 
et al. 2000 and Francis et al. 2005). Support can also be found in the VC literature, Cohen and Langberg (2005) finding that, on average, reported earnings are less informative for VC-backed firms, and that the value of, and information within, reported earnings decrease as a function of VC ownership.

Consistent with the financial reporting discipline created by PE sponsors, my next hypothesis (stated in alternative form) is:

H2: PE-backed firms are more likely than non-PE-backed firms to recognize losses in a timely fashion.

\section{Post-IPO Abnormal Returns and Financial Performance}

Having tested the effect of ownership structure (PE-backed versus non-PE-backed) on earnings quality, I next test whether ownership structure also affects long-term reported financial performance and market abnormal returns in the post-IPO period.

I expect PE-backed firms to have better long-term financial performance and market abnormal returns than non-PE-backed firms. To the extent that PE-backed firms, as hypothesized above, have lower pre-IPO discretionary accruals than non-PE-backed firms, reported earnings in the post-IPO years as well as overall reported financial performance are expected to reverse and deteriorate to a lesser degree (Teoh, Wong, and Rao 1998). This better earnings quality is also predicted to lead to relatively higher market abnormal returns (Chou et al. 2006). Furthermore, in addition to giving financial and strategic advice, PE sponsors play a monitoring

role in their portfolio firms (Gompers 1995, Lerner 1995), and tighter monitoring is documented to lead to better earnings quality (Wongsunwai 2007) as well as better long-term financial performance (Ivanov et al. 2008) and better market abnormal returns (Cao and Lerner 2006). 
I noted above the counter argument that PE-backed firms' decision to return to public listing is driven by opportunistic behavior and IPO timing. If PE-backed firms go public because they have exhausted the benefits of the LBO ownership form or their profits are insufficient to cover their debt load, their operating performance following the IPO would be expected to deteriorate to a greater extent than that of non-PE-backed firms (Degeorge and Zeckhauser 1993). Furthermore, improvements in the financial performance of PE-backed firms that go private can also be explained by agency theory, in particular, greater goal congruence between owners and management, stronger incentives to create shareholder wealth as management's ownership stake increases, and the disciplinary role of higher leverage (Kaplan 1991, Holthausen and Larcker 1996, Bruton et al. 2002). When a company returns to public listing, manager and owner interests and incentives once again diverge, monitoring costs increase, leverage decreases, and agency theory, as noted above, predicts a reintroduction of inefficiencies and loss of previously experienced performance gains (Bruton et al. 2002). Finally, other factors such as managerial risk aversion or managerial entrenchment might occasion performance increases following a reverse buyout of management-owned as opposed to PE-backed firms (Holthausen and Larcker 1996).

Consistent with the higher earnings quality and better monitoring and control associated with PE sponsor owners, my next hypothesis (stated in alternative form) is:

H3: PE-backed firms are likely to have better long-term financial and stock price performance in the post-IPO period than non-PE-backed firms. 


\section{SAMPLE SELECTION AND RESEARCH DESIGN}

\section{Sample Selection}

My sample of private firms with public debt covers all firm-year observations on COMPUSTAT for any of the 28 years from 1978 through 2005 that satisfy the following criteria: ${ }^{19}$ (1) the firm's stock price at fiscal year end is unavailable; (2) the firm has total debt as well as total annual revenue exceeding \$1 million; (3) the firm is a separate domestic company; and (4) the firms is not a subsidiary of another public firm. I further exclude financial institutions and firms in regulated industries (SIC codes 6000-6999 and 4800-4900).

To ensure that my sample includes only private firms with public debt, I examine each firm and remove public firm observations (details are provided in Table 1) ${ }^{20}$ I further categorize each firm as being in one of the following pre-IPO, mutually exclusive categories: (1) PE majorityowned, defined as firms that are majority-owned (more than 50\%) by PE sponsors; ${ }^{21}$ (2) PE minority-owned, defined as firms that are minority-owned (equal to or less than 50\%) by PE sponsors; (3) management-owned, defined as firms having no PE sponsor ownership and that are at least $50 \%$ owned by the founders, executives, and directors, or family members; (4) employeeowned, defined as firms having no PE sponsor ownership and that are at least $50 \%$ owned by their employees; and (5) unknown, defined as there being no information available on firm ownership. Finally, I identify changes in organization type due to equity IPOs, mergers and acquisitions, bankruptcies, and deregistration (form type 15-15D). The resulting sample, which

\footnotetext{
${ }^{19}$ Prior to 1980 , leveraged takeover activity was limited and few private firms held public debt. Indeed, one of the first instances (if not the first) of a private firm with public debt was Movado in 1979.

${ }^{20}$ Because some public firms met the above criteria as a result of missing price data, to further determine whether firms qualified as private firms with public debt, I hand-collected SEC filings information from EDGAR and 10K Wizard, bankruptcy information from BankruptcyData.com, and other historical information from Hoover's DataBase as well as from several news resources including Factiva, ProQuest, and LexisNexis. I omitted 355 firmyear observations of cooperatives, limited partnerships, and government-owned firms that might have different earnings management incentives resulting from their organizational and ownership structures.

${ }^{21}$ The list of PE sponsors was taken from the Thomson Financials VentureXpert database.
} 
includes 2,810 firm-year observations and 557 private firms (for the years 1980-2005), is used for the descriptive statistics reported in Table 2.

To focus the analysis on the period surrounding the IPO, defined as five years before and five years after the IPO, I further remove all non-IPO firms. The final sample, which includes 123 PE-backed (both majority- and minority-owned) IPOs and 24 management-owned IPOs (hereafter referred to as non-PE-backed, or management-owned, firms), is used for the analyses that follow. ${ }^{22}$

I identify the IPO date and first-day-of-trading returns using the Corporate New Issues database of Securities Data Company (SDC). For the returns analysis, I require that each IPO be listed in CRSP. For firms in the pre-IPO phase, corporate governance information (e.g., board characteristics, compensation structure) is collected from $10 \mathrm{Ks}$ and proxies in the year prior to the IPO. I use prospectus information to identify changes in corporate governance post-IPO, and the Thomson Financials VentureXpert database to rank PE sponsors according to total investment (in \$US).

\section{Research Design: Earnings Management}

\section{$\underline{\text { Unexpected Discretionary Accruals }}$}

In order to be able to compare my findings to prior research, I use as my comprehensive measure of earnings management the cross-sectional modified Jones (1991) model. The Jones model regresses total accruals on the change in sales, after subtracting the change in trade

\footnotetext{
${ }^{22}$ I use the Heckman (1979) two-stage procedure described at the end of section III to account for the possible endogeneity of the choice of going public or receiving PE financing. I do not perform separate analyses for the other ownership and organizational forms due to the small number of observations. The main results are unchanged when management-owned and employee-owned firms are combined as non-PE-backed firms.
} 
receivables and level of property, plant, and equipment for a test sample of all public firms in the same two-digit SIC code and year. ${ }^{23}$

Though widely used in the earnings management literature, accruals models such as the modified Jones model are far from perfect in detecting earnings management. Because the models assume the relationship between cash flows and accruals to be linear, thus ignoring the asymmetry in the gain and loss recognition of accruals, I incorporate in the estimation of the modified Jones model the improvement in accruals models proposed by Ball and Shivakumar (2006a). Specifically, I add to the model a proxy for potentially reportable gains and losses in the form of the sign of the cash flows from operations. Consistent with the results reported by Ball and Shivakumar (2006a), the introduction of this proxy increases the explanatory power of the model considerably. ${ }^{24}$

Because performance might be a key driver of both a firm's decision to go public and PE sponsors' provision of financial backing (Morsfield and Tan 2006), I employ in an untabulated analysis the Kothari et al. (2005) performance-matching approach. ${ }^{25}$ For the year of IPO, I also report the results of the current unexpected discretionary accruals model derived from the cross-

\footnotetext{
${ }^{23}$ Specifically, I estimate the following regression cross-sectionally, and further require that at least ten observations be available before performing each regression:

$\mathrm{TACC}_{\mathrm{j}, \mathrm{t}} / \mathrm{TA}_{\mathrm{j}, \mathrm{t}-1}=\mathrm{a}_{1} *\left[1 / \mathrm{TA}_{\mathrm{j}, \mathrm{t}-1}\right]+\mathrm{a}_{2} *\left[\left(\Delta \mathrm{REV}_{\mathrm{j}, \mathrm{t}}-\Delta \mathrm{TR}_{\mathrm{j}, \mathrm{t}}\right) / \mathrm{TA}_{\mathrm{j}, \mathrm{t}-1}\right]+\mathrm{a}_{3} *\left[\mathrm{PPE}_{\mathrm{j}, \mathrm{t}} / \mathrm{TA}_{\mathrm{j}, \mathrm{t}-1}\right]$

where: $T A C C_{j}$, is total accruals for firm $\mathrm{j}$ in year t. Following Hribar and Collins (2002), I define total accruals as the difference between income before extraordinary items (\#123) and net cash flow from operating activities, adjusted to extraordinary items and discontinued operations (\#308 - \#124). For the years prior to 1988, when COMPUSTAT item \#308 is unavailable, I define total accruals as follows: $\Delta$ (current assets \#4) $-\Delta$ (current liabilities \#5) $-\Delta$ (cash $\# 1)+\Delta$ (short-term debt \#34) - (depreciation and amortization \#125). $T A_{j, t-l}$ is the beginning-of-the-year total assets (lagged \#6). $\triangle R E V_{j}$, is the change in sales in year $\mathrm{t}(\# 12), P P E_{j}$, is gross property, plant, and equipment in year $\mathrm{t}(\# 7)$ ), and $\Delta T R_{j}$, is the change in trade receivables in year $\mathrm{t}(\# 151)$. In addition, to correct for measurement errors in the balance-sheet approach prior to 1988, I eliminated firm-year observations with "non-articulation" events: merger or acquisition, discontinued operations, and gain or loss on foreign currency translations (Hribar and Collins 2002).

${ }^{24}$ In particular, I augmented the modified Jones model with the following independent variables: cash flow from operations in year $\mathrm{t}\left(\mathrm{CF}_{\mathrm{t}}\right)$, a dummy variable set to 1 if $\mathrm{CF}_{\mathrm{t}}<1$ and 0 otherwise $\left(\mathrm{DCF}_{\mathrm{t}}\right)$, and an interactive variable, $\mathrm{CF}_{\mathrm{t}} \times \mathrm{DCF}_{\mathrm{t}}$ (Ball and Shivakumar 2006a).

${ }^{25}$ Specifically, I use the performance measure suggested by Kothari et al. (2005), ROA, which is defined as net income (COMPUSTAT data item \#172) plus net of tax interest expense (\#15) divided by total assets at end of year t-1 (lagged \#6). I match each observation by industry, year, and the deciles of ROA in the same industry and year.
} 
sectional modified Jones model used by Teoh et al. (1998a, 1998b), Morsfield and Tan (2006), and Chou et al. (2006). ${ }^{26}$

\section{$\underline{\text { Additional Earnings Management Measure }}$}

Following Penman and Zhang (2004), the operating activities for clean surplus relation leads to Operating Income I, $\mathrm{t}=$ Free Cash Flow $_{\mathrm{j}, \mathrm{t}}+\Delta \mathrm{NOA}_{\mathrm{j}, \mathrm{t}}$. The free cash flow is the "hard" aspect, $\Delta \mathrm{NOA}_{\mathrm{j}, \mathrm{t}}$ the "soft" aspect, of the operating income calculation, which involves discretionary measurements and estimations. ${ }^{27} \Delta \mathrm{NOA}_{\mathrm{j}, \mathrm{t}}$ can therefore be used as an additional signal of earnings management, where:

growth in net operating assets: $\mathrm{GNOA}_{\mathrm{j}, \mathrm{t}}=\left(\mathrm{NOA}_{\mathrm{j}, \mathrm{t}}-\mathrm{NOA}_{\mathrm{j}, \mathrm{t}-1}\right) / \mathrm{NOA}_{\mathrm{j}, \mathrm{t}-1} \mid$

Because changes in measures can be attributed to external factors and period effects, following prior literature (Teoh et al. 1998b), I report the differences between the GNOA measure for each firm and the median measure for the same year and industry (4-digit SIC codes if there are at least five non-IPO firms, otherwise 3-digit SIC codes or 2-digit SIC codes with at least five observations).

To minimize survivorship bias, I report the average of five years' annual UTACC and GNOA variables, using the maximum number of years for which COMPUSTAT data is available

\footnotetext{
${ }^{26}$ Current accruals are defined as the difference between the change in noncash current assets and the change in current operating liabilities. The unexpected discretionary accruals are estimated from a cross-sectional regression, in the same year and industry, of current accruals on the change in sales, both scaled by prior year total assets.

${ }^{27}$ I define NOA as follows. Common equity: [common equity (\#60) + preferred treasury stock (\#227) - preferred dividends in arrears (\#242)] + financial obligations: [debt in current liabilities (\#34) + total long-term debt (\#9) + preferred stock (\#130) - preferred treasury stock (\#227) + preferred dividends in arrears (\#242)] - financial assets: [cash and short-term investments (\#1) + investments and advances minus other (\#32)] + minority interest (\#38).

I define Operating Income as follows. Earnings: [net income (\#172) - preferred dividends (\#19) + change in marketable securities adjustment (change in \#238) + change in cumulative translation adjustment (change in \#230)] + net interest expense: [after-tax interest expense $(\# 15 \times(1$ - marginal tax rate $))+$ preferred dividends (\#19) - aftertax interest income $(\# 62 \times(1$ - marginal tax rate) $)+$ minority interest in income (\#49) minus the change in marketable securities adjustment (change in \#238)], where the marginal tax rate is the top statutory federal tax rate plus $2 \%$ average state tax rate. The top federal statutory corporate tax rate was $48 \%$ in $1971-1978,46 \%$ in 19791986, 40\% in 1987, 34\% in 1988-1992, and 35\% in 1993-2005 (Nissim and Penman 2003).
} 
for firms that do not survive for five full years after their IPO (for further discussion, see Ivanov et al. 2008).

Multivariate Earnings Management Analysis

I also estimate the following regression, which allows for differences in earnings management between PE-backed and non-PE-backed firms in order to test H1:

$$
\begin{aligned}
\mathrm{EM}_{\mathrm{t}}= & \mathrm{a}_{0}+\mathrm{a}_{1} * \mathrm{PE}+\mathrm{a}_{3} * \text { Size }_{\mathrm{t}}+\mathrm{a}_{4} * \mathrm{BV}_{\mathrm{t}}+\mathrm{a}_{5} * \text { Growth }_{\mathrm{t}}+\mathrm{a}_{6} * \text { Leverage }_{\mathrm{t}}+\mathrm{a}_{7} * \text { Profitability }_{\mathrm{t}}+ \\
& \mathrm{a}_{8} * \mathrm{QRatio}_{\mathrm{t}}+\mathrm{a}_{9} * \text { Oper_Cycle } \\
& \mathrm{a}_{14} * \mathrm{a}_{10} * \text { Age }_{\mathrm{t}}+\mathrm{a}_{11} * \text { Cash }_{\mathrm{t}}+\mathrm{a}_{12} * \mathrm{CAPEX}_{\mathrm{t}}+\mathrm{a}_{13} * \mathrm{D}_{-} \text {Loss }_{\mathrm{t}}+
\end{aligned}
$$

where: $E M_{t}$ is a measure of earnings management, alternatively defined as $\mathrm{UTACC}_{\mathrm{t}}$ and $\mathrm{GNOA}_{\mathrm{t}}$. $P E$ is a dummy variable with the value 1 for PE-backed private firms (both majority- and minority-owned) and 0 for firms owned by management. Size is alternatively defined as the natural logarithms of total assets (\#6) or sales (\#12). $B V$ is equity book value $(\# 60+\# 130+35 \#)$ divided by total assets. Growth is defined as growth in sales. Leverage is defined as total debt $(\# 9+\# 34)$ divided by total assets. Profitability is defined as operating income divided by net operating assets (RNOA). QRatio is the quick ratio, defined as cash and short-term investment (\#1) plus total receivables (\#2) divided by current liabilities (\#5). Oper_Cycle is operating cycle days (receivable collection period plus inventory turnover in days). Age is defined as number of years since incorporation (first appearance on COMPUSTAT). Cash is cash and short-term investment divided by total assets. CAPEX is capital expenditures (\#128) divided by total assets. D_Loss is a dummy for loss firms (\#172) and D_Audit_Quality a dummy for the big national accounting firms (\#149). ${ }^{28}$

\footnotetext{
${ }^{28}$ The above control variables were used in the prior literature in the context of IPOs and the choice of private equity financing, in particular, size, growth, leverage, and profitability (Chou et al. 2006, Morsfield and Tan 2006), and age, investments, and liquidity (Beuselinck et al. 2005). The audit firm's size was added because it can influence firms' earnings management and timely loss recognition (Aharony et al. 1993, Basu et al. 2001, Morsfield and Tan 2006).
} 


\section{Research Design: Timely Loss Recognition}

Earnings are more conservative when losses are recognized in a timely manner, as emphasized by Basu (1997), in whose model stock returns are used as a proxy for economic gains and losses. Ball and Shivakumar (2005), who do not have stock returns for their sample of pure private firms, use changes in accounting income as the independent variables associated with transitory gains and losses. In a similar way, I estimate the following variation of Basu's regression to allow for differences in timely loss recognition between PE-backed and non-PEbacked firms in order to test $\mathbf{H 2}:^{29}$

$$
\begin{aligned}
\Delta \mathrm{OpI}_{\mathrm{t}} & =\mathrm{a}_{0}+\mathrm{a}_{1} * \mathrm{D} \Delta \mathrm{OpI}_{\mathrm{t}-1}+\mathrm{a}_{2} * \Delta \mathrm{OpI}_{\mathrm{t}-1}+\mathrm{a}_{3} * \mathrm{D} \Delta \mathrm{OpI}_{\mathrm{t}-1} * \Delta \mathrm{OpI}_{\mathrm{t}-1}+\mathrm{a}_{4} * \mathrm{PE}+\mathrm{a}_{5} * \mathrm{PE}^{*} \mathrm{D} \Delta \mathrm{OpI}_{\mathrm{t}-1}+ \\
& +\mathrm{a}_{6} * \mathrm{PE}^{*} \Delta \mathrm{OpI}_{\mathrm{t}-1}+\mathrm{a}_{7} * \mathrm{PE}^{*} \mathrm{D} \Delta \mathrm{OpI}_{\mathrm{t}-1} * \Delta \mathrm{OpI}_{\mathrm{t}-1}+\mathrm{e}_{\mathrm{t}}
\end{aligned}
$$

where: $\Delta O p I_{t}$ is changes in earnings from year $\mathrm{t}-1$ to year $\mathrm{t}$, standardized by total assets at the

end of year $\mathrm{t}-1$. Earnings are measured before interest expense and interest income $(\mathrm{OpI}){ }^{30}$ $D \Delta O P I_{t-1}$ is a dummy variable that gets the value 1 if $\Delta \mathrm{OpI}_{\mathrm{t}-1}<0$ and 0 otherwise. $P E$ is a dummy variable with the value 1 for PE-backed firms and 0 for non-PE-backed firms.

I predict that the involvement of PE sponsors leads to a higher level of earnings quality, as measured by more timely loss recognition. As a result, I anticipate that persistent gain recognition will be greater for PE-backed than for non-PE-backed private firms, and therefore expect $\mathrm{a}_{6}>0$. I also expect timely loss recognition to be greater for PE-backed than for non-PEbacked private firms, and therefore expect $\mathrm{a}_{7}<0$.

That the timely loss recognition identified above is a result neither of random errors in accruals nor of earnings management is supported by the results of an alternate model developed by Ball and Shivakumar (2005) that recognizes unrealized gains and losses via accruals. Dechow

\footnotetext{
${ }^{29}$ This variation on Ball and Shivakumar's (2005) regression was used in Beuselinck et al. (2005). I further estimate regressions (5) and (6) separately for the pre- and post-IPO periods.

${ }^{30}$ The results remain qualitatively similar when I measure, in an untabulated analysis, earnings before and after extraordinary items.
} 
et al. (1998) show that accruals can mitigate the noise in operating cash flow and lead to a negative correlation between accruals and cash flow. Ball and Shivakumar (2005) also identify a second role of accruals: timely recognition of economic gains and losses leads to a positive but asymmetric correlation between accruals and contemporaneous cash flow. Ball and Shivakumar (2005) maintain that the asymmetry in the accruals model exists because in non-cash items there is more timely recognition of economic losses than of economic gains. Therefore, the second role of accruals is greater in the case of losses. Following Beuselinck et al. (2005), I run the following variation of Ball and Shivakumar's (2005) regression:

$$
\begin{aligned}
\mathrm{ACC}_{\mathrm{t}}= & \mathrm{b}_{0}+\mathrm{b}_{1} * \mathrm{DCFO}_{\mathrm{t}}+\mathrm{b} 2 * \mathrm{CFO}_{\mathrm{t}}+\mathrm{b} 3 * \mathrm{DCFO}_{\mathrm{t}} * \mathrm{CFO}_{\mathrm{t}}+\mathrm{b}_{4} * \mathrm{PE}+\mathrm{b}_{5} * \mathrm{PE} * \mathrm{DCFO}_{\mathrm{t}}+ \\
& +\mathrm{b}_{6} * \mathrm{PE} * \mathrm{CFO}_{\mathrm{t}}+\mathrm{b}_{7} * \mathrm{PE} * \mathrm{DCFO}_{\mathrm{t}} * \mathrm{CFO}_{\mathrm{t}}+\mathrm{e}_{\mathrm{t}}
\end{aligned}
$$

where: $A C C_{t}$ is total accruals in year $\mathrm{t}$, standardized by beginning-of-the-year total assets. For the definition of accruals, see the discussion of abnormal accruals above. Following Hribar and Collins (2002), $C F O_{t}$ is defined, for years after 1988, as cash from operations in year t, adjusted to extraordinary items and discontinued operations (\#308 - \#124), and standardized by total assets at end of year $\mathrm{t}-1 .{ }^{31} \mathrm{DCFO} \mathrm{O}_{t}$ is a dummy variable that takes the value 1 if $\mathrm{CFO}_{\mathrm{t}}<0$ and 0 otherwise. $P E$ is as defined above.

Following Ball and Shivakumar (2005), I predict that the above model will demonstrate the strong role of accruals in mitigating noise in operating cash flow. I therefore expect $b_{2}<0$. I also predict that PE sponsor involvement leads to higher earnings quality, which, in turn, leads to a positive but asymmetric correlation between accruals and contemporaneous cash flow. I therefore predict that the coefficient $b_{7}>0$.

\footnotetext{
31 Following Xie (2001), for years prior to 1988, I define cash flow from operations as funds from operations $(\text { COMPUSTAT data item \#110) }-\Delta \text { (current assets \#4) })_{\mathrm{t}}+\Delta(\text { cash and cash equivalent } \# 1)_{\mathrm{t}}+\Delta(\text { current liabilities } \# 5)_{\mathrm{t}}$ $-\Delta($ short-term debt \#34) . All variables are divided by total assets at end of year $\mathrm{t}-1$ (lagged \#6).
} 
I account for the possible endogeneity of receiving PE financing by using the Heckman (1979) two-stage procedure. In the first stage, I estimate a PROBIT model with, as predictors, size (alternatively defined as the natural logarithms of total assets or sales), ratio of book value of equity to total assets, growth (in sales), leverage, profitability (RNOA), quick ratio, length of the operating cycle, age, cash and capital expenditures (both divided by total assets), a dummy for loss firms, and audit quality (a dummy for the big national accounting firms). Estimates of the PROBIT model are used to compute the inverse Mills' ratio for each sample firm. In the second stage, I include the inverse Mills' ratio as a control variable in regressions (2), (3), and (4) and allow the coefficient to vary between the two groups of firms. (For similar implementations, see Ball and Shivakumar 2005, Beuselinck et al. 2005, Hochberg 2006, and Givoly et al. 2007b).

\section{Research Design: Abnormal Returns and Financial Performance}

For each IPO, the adjusted size and book-to-market matched returns are calculated as the buy-and-hold daily returns for the periods of one year, three years, and five years after the IPO, less the buy-and-hold returns on a benchmark of a value-weighted size and book-to-market matched control sample for the same period (the daily matched portfolio returns as well as the relevant breakpoints are from Kenneth French's Web site). ${ }^{32}$ If the sample firm delists during the relevant period, I add the delist return to the firm's buy-and-hold return and set the size and book-to-market matched return equal to zero after the delisting date. When the delisting return is missing, following Shumway and Warther (1999) and the CRSP "white paper" on delisting returns (2001), I allocate it in accordance with the delisting code and exchange code.

To avoid the problem of overlapping periods in the estimation of buy-and-hold returns, following Chou et al. (2006) and Fan (2007), I also estimate the value-weighted monthly

\footnotetext{
${ }^{32}$ http://mba.tuck.dartmouth.edu/pages/faculty/ken.french/data_library.html.
} 
abnormal returns based on calendar time using the Fama and French (1993) three factor model. Specifically, I regress the monthly returns (in excess of the risk free-rate) on the three factors as in the following regression:

$\mathrm{R}_{\mathrm{pt}}-\mathrm{R}_{\mathrm{ft}}=\mathrm{a}_{\mathrm{p}}+\mathrm{b}_{\mathrm{p}}\left(\mathrm{R}_{\mathrm{mt}}-\mathrm{R}_{\mathrm{ft}}\right)+\mathrm{s}_{\mathrm{p}} \mathrm{SMB}_{\mathrm{t}}+\mathrm{h}_{\mathrm{p}} \mathrm{HML}_{\mathrm{t}}+\varepsilon_{\mathrm{t}}$

where: $R_{p t}$ is the equally weighted portfolio returns in calendar month t, $R_{f t}$ is the 30-day T-bill yield in month t, $R_{m t}$ is the return on the value weighted CRSP index, $S M B_{t}$ is the return on small firms minus the return on large firms, and $H M L_{t}$ is the return on high book-to-market stocks minus the return on low book-to-market stocks in month t. The regressions are carried out separately for each ownership stake and for different sizes of PE sponsors. The estimate of the intercept coefficient $\left(\mathrm{a}_{\mathrm{p}}\right)$ is a measure of average monthly abnormal returns.

I use three measures of long-run financial performance for the periods of one year, three years, and five years after the IPO: industry adjusted operating performance; market-to-book ratio; and a stock exchange delisting measure (for similar implementations, see Ivanov et al. 2008, Moeller et al. 2004, Gompers et al. 2003, and Field and Karpoff 2002).

The first measure is industry-adjusted operating performance (ROA), which I use to calculate the average matched-adjusted return on assets for the periods after the IPO. ROA is defined as net income (\#172) plus net of tax interest expense (\#15) divided by total assets at end of year t-1 (lagged \#6), minus the industry median ROA for the same period (based on 4-digit SIC codes if there are at least five non-IPO firms, otherwise the 3-digit SIC codes or 2-digit SIC codes with at least five observations). For firms that do not survive for one year, three years, or five years after the IPO, the maximum number of years for which COMPUSTAT data is available is used. The second measure is the market-to-book ratio as measured at the end of one year, three years, or five years since the IPO. For firms that do not survive for the full period after the IPO, the maximum number of years for which COMPUSTAT data is available is used. 
Market value of equity is defined as common shares outstanding (\#25) multiplied by the fiscal year closing price (\#199). Book value of equity is defined as total common equity (\#60) + carrying value of preferred stock $(\# 130)+$ deferred taxes and investment tax credit (\#35). The third measure, stock exchange delisting, is defined as the percentage of firms delisted from the NYSE, AMEX, or NASDAQ due to bankruptcy, default, or liquidation (CRSP delisting codes 400 and above).

Lastly, prior literature having suggested that lead underwriter reputation can affect longrun IPO returns (e.g., Carter et al. 1998), I report and control for the reputation ranking of IPO underwriting. ${ }^{33}$

All returns analyses are performed separately for different ownership stakes and different sizes of PE sponsors.

\section{DESCRIPTIVE STATISTICS}

\section{Descriptive Statistics: Private Firms with Public Debt}

Column 1 of Table 2, Panel A includes descriptive statistics for the entire sample of private firms with public debt (2,810 firm-year observations for 557 firms). The remaining data in Table 2, Panel A shows the distribution of firms and firm-year observations among various ownership forms.

Private firms majority-owned by PE sponsors make up 57\% of the firms in the sample; $14 \%$ are minority-owned by PE sponsors, $22 \%$ owned by management. ${ }^{34}$ Firms that are majorityor minority-owned by PE sponsors have the highest leverage (means of $76.5 \%$ and $77.9 \%$, respectively, versus total sample mean of $68.0 \%$ ), and firms that are majority-owned by PE

\footnotetext{
${ }^{33}$ These rankings, available on Jay Ritter's Web site: http://bear.cba.ufl.edu/ritter/rank.xls, vary from one to nine, nine being the best reputation, and are updated.

${ }^{34}$ Because several firms changed ownership structure during the period, the total number of firms adds up to 568 .
} 
sponsors have the lowest assets, sales growth, and ROA. However, as Panel B shows, the different ownership forms have a similar industry representation and there is no particular industry clustering.

As can be seen in Panel C, PE-backed firms have the highest concentration of belowBBB-ranked debt (68.1\% and $62.3 \%$ for majority-owned and minority-owned PE-backed firms, respectively, versus total sample mean of 55.5\%). As can be seen in Panel D, they are also more likely to file for bankruptcy protection $(17.2 \%$ and $19.5 \%$, respectively, versus total sample mean of $16.2 \%$ ). These observations are not surprising inasmuch as PE sponsors tend to be involved in LBO and MBO activities, which increase debt levels and, hence, the overall risk of default. Moreover, PE-backed private firms (both majority- and minority-owned) are more likely to exit via equity IPO (30.1\% and $35.1 \%$, respectively, versus total sample mean of $28.4 \%)$. This result is consistent with the goal of PE sponsors to monetize their investments through an IPO or M\&A transaction.

Table 2, Panel E shows that $15.3 \%$ of the PE-backed firms in the sample are owned by the 14 largest PE sponsors in the market.

\section{Descriptive Statistics: Pre-IPO and Post-IPO Periods}

Table 3 presents descriptive statistics for 123 PE-backed firms (96 majority-owned and 27 minority-owned) and 24 non-PE-backed firms (management-owned) that had IPOs. This table compares the firms under the different ownership structures and during two periods: five years pre-IPO and five years post-IPO. Consistent with the results in Table 2, Panel A, the PE-backed firms have significantly higher leverage than the non-PE-backed firms in the pre- and post-IPO periods. PE-backed firms also have significantly lower quick ratios and cash as a percentage of 
assets. Moreover, for both PE-backed and non-PE-backed firms, leverage is significantly higher in the pre-IPO than in the post-IPO period. This result is not surprising given that many of the pre-IPO firms went through an LBO or MBO, which was why they had issued public debt.

Untabulated analysis further reveals that the involvement of PE-backed and non-PEbacked firms in restructuring activity (as indicated by discontinued operations, M\&A activity, and increases or decreases in asset growth greater than 50\%) is not significantly different in the period surrounding an IPO. As indicated in Table 3, however, the proportion of special items is significantly higher for majority PE-backed than for non-PE-backed firms in the pre-IPO period. To control for these differences, I conduct the conservatism analyses on operating income definitions that exclude such special items.

\section{Descriptive Statistics: Corporate Governance}

Table 4 presents descriptive statistics for corporate governance among both PE-backed firms (both majority- and minority-owned) and management-owned firms in the pre-IPO period. As Cao and Lerner (2006) report, PE sponsors have a large ownership stake $(79.9 \%$ and 36.4\%, respectively, for firms that are majority- and minority-owned by PE sponsors) and actively monitor managers. Indeed, $55.2 \%$ and $34 \%$, respectively, of the boards of directors are from or affiliated with PE sponsor groups, and PE-backed firms' boards are significantly larger than those of management-owned firms. Moreover, in PE-backed firms, a greater proportion of CEO pay is in the form of equity and variable compensation (mainly options and bonuses), which is consistent with giving the $\mathrm{CEO}$ an incentive to take the company public (Cadman and Sunder

2007). ${ }^{35}$ As further indicated by the post-IPO panel, PE sponsors retain a significant ownership

\footnotetext{
${ }^{35}$ In some instances, PE-backed firms tie the CEO's bonus to cash-flow performance and EBITDA. For example, this appeared in the 1997 10K of Family Restaurants (majority-owned by Apollo Partners): "The Company's
} 
stake (48.9\% and $20.8 \%$, respectively, for majority- and minority-owned firms) in the post-IPO period, ${ }^{36}$ and continue to monitor managers $(50.3 \%$ and $29.4 \%$, respectively, of the boards of directors are from or affiliated with PE sponsor groups).

\section{EMPIRICAL RESULTS}

\section{Results: Earnings Management}

The results of estimating earnings management by abnormal accruals (UTACC) and industry adjusted growth in net operating assets (GNOA) are provided in Table 5, Panel A. ${ }^{37}$ Consistent with my prediction that earnings are managed upward to a lesser extent by PE-backed than by non-PE-backed firms, the first line of results in Table 5 indicates that the UTACC means of firms that are majority- and minority-owned by PE sponsors are $-3.7 \%$ and $-4.2 \%$, respectively, whereas the mean for management-owned firms is $-0.3 \%$. The differences of $-3.4 \%$ and $-3.9 \%$ are significant at the 0.01 level. Similar results are obtained for the differences in GNOA, when making the comparison on medians, and for the post-IPO period (also after including average information in order to minimize any survival bias). Excepting the significantly less negative GNOA for the majority-PE-owned firms in the pre-IPO period, the analysis reveals no significant differences between firms that are majority-owned and minorityowned by PE sponsors. ${ }^{38}$

President and Chief Executive Officer ... entered into an Employment Agreement with the Company ... providing for annual compensation of not less than $\$ 400,000$, to increase to $\$ 500,000$ upon the attainment of $\$ 40,000,000$ in Company EBITDA."

${ }^{36}$ An untabulated analysis further reveals that five years after the IPO, PE sponsors retain a significant ownership stake (26.8\% and $16.4 \%$, respectively, for majority- and minority-owned firms), as compared to $22.9 \%$ ownership stake by management for non-PE-backed firms.

${ }^{37}$ Although the hypotheses are stated as one-sided, all empirical results are conducted as two-sided tests.

${ }^{38}$ Untabulated analyses indicate that the main abnormal accruals results remain qualitatively unaltered when I use other specifications of the Jones model such as current accruals (with or without control for timely loss recognition and the balance sheet approach) and the Kothari et al. (2005) performance-matching approach. 
These results also hold when I repeat the analysis for the year-by-year, before and after IPO. For most of the years, the differences in both means and medians are more negative for PEbacked than for non-PE-backed firms. ${ }^{39}$

I do not interpret the results during the IPO year because receipt of IPO proceeds, being associated with explosive growth, can affect accruals and working capital (Ball and Shivakumar 2006b). Following prior literature, I also report in the last line of Table 5, Panel A the results of an abnormal current accruals model for the year of IPO. These results are similar in magnitude to those obtained for PE-backed firms by Chou et al. (2006), who find only weak evidence that PE-backed firms have higher discretionary accruals than non-PE-backed firms, but, due to the small sample size, could not conclude that PE sponsors' involvement was associated with greater earnings management. In my sample, there is a weak contrary indication.

Table 5, Panel B reports the results of regression (2) for the sample of pre- and post-IPO firms under two specifications: (1) including control for possible endogeneity, and (2) including control variables (as defined in section III). In both periods, for both earnings management measures, and under both specifications, the coefficients, $a_{1}$, the dummy variables for PE-backed firms are negative, by and large significantly so, indicating that earnings are managed upward to a lesser extent by PE-backed firms than by non-PE-backed firms. Moreover, the coefficients of the inverse Mills' variables (lambda) are significant when performing the regression on GNOA, suggesting the presence of endogeneity and the appropriateness of controlling for it. ${ }^{40}$

\footnotetext{
${ }^{39}$ The reported results for the five years pre-IPO and five years post-IPO (but not for the year-by-year analyses) exclude firm-year observations during restructuring periods. When performed on the entire sample, the results are qualitatively similar.

${ }^{40}$ If firms select PE financing based on either expected abnormal accruals or expected growth in net operating assets, the dummy variable PE is endogenous. It is more likely in the GNOA regression because GNOA is correlated with growth and profitability, which were identified by prior literature as being associated with the choice of PE financing (Chou et al. 2006, Morsfield and Tan 2006). This association was further confirmed by the first stage probit model.
} 
Untabulated analyses further reveal the foregoing results to hold for the comparison of both majority- and minority-PE-owned firms versus management-owned firms.

Overall, and consistent with H1, these results indicate that non-PE-backed firms manage earnings upward to a greater extent than PE-backed firms (both majority- and minority-owned), as indicated by the significantly higher abnormal accruals and GNOA. This is consistent with the prediction that PE sponsors restrain earnings management.

\section{Results: Timely Loss Recognition}

Table 6 reports the results of regression (3) for the sample of pre- and post-IPO firms under three specifications: (1) excluding control variables, (2) including control for possible endogeneity, and (3) including control variables.

For non-PE-backed private firms in the pre-IPO period, the coefficients, $\mathrm{a}_{2}$, on prior positive earnings changes are significantly negative, indicating timely recognition of economic gains (on average, approximately $45 \%$ to $105 \%$ reversal of income increases). The incremental coefficients, $a_{3}$, on prior negative earnings changes are positive (but significant only under specifications (2) and (3)) indicating that losses are recognized in a less timely manner than gains. The sum of the coefficients $a_{2}+a_{3}$ is negative under all specifications, but relatively small (coefficients' sums range from -0.05 to -0.30 ), indicating timely loss recognition, which leads to a reversal of income decreases (on average, approximately 5\% to 30\%). Taken together, these results suggest that non-PE-backed private firms appear to have low earnings quality as measured by deferred loss recognition.

The incremental coefficients on earnings increases for PE-backed private firms, $\mathrm{a}_{6}$, are significantly positive under the three specifications (with coefficients of $0.55,0.74$, and 1.19 , and 
t-values of $1.68,2.30$, and 5.12, respectively), indicating that PE-backed private firms are more likely than non-PE-backed private firms to defer recognition of economic gains. As I further predicted, the incremental coefficients on earnings, a7, decreases for PE-backed firms, and the sum of the coefficients, $a_{3}+a_{7}$, is significantly negative under all specifications, indicating that PE-backed private firms are more likely than non-PE-backed private firms to incorporate transitory losses in income.

Table 6 also presents the results of regression (3) for the sample of post-IPO firms. The sum of the coefficients, $a_{3}+a_{7}$, is significantly negative under the three regression specifications, and the main coefficient of interest, $a_{7}$, is negative (but significant only under specifications (1) and (2)).

Taken together, and consistent with $\mathbf{H 2}$, PE-backed private firms have higher-quality earnings reporting than non-PE-backed private firms in both the pre-IPO and post-IPO periods.

Table 7 reports the results of regression (4), under the above three specifications, for the sample of pre- and post-IPO firms.

In the case of non-PE-backed pre-IPO private firms, the coefficient on prior positive cash flow, $b_{2}$, is significantly negative (with coefficients of $-0.28,-0.38$, and -0.62 , and t-values of $-2.38,-2.51$, and -3.94 , for the three specifications, respectively), indicating that, on average, between $28 \%$ and $62 \%$ of cash flow is mitigated by accruals in years with positive cash flow. This finding is consistent with the role of accruals in mitigating noise in operating cash flow. The coefficient on prior negative cash flow, $b_{3}$, is negative as well (but insignificant under specification (2)), indicating that non-PE-backed private firms mitigate noise in cash flow to an even greater degree in years with negative operating cash flow. 
The incremental coefficient, $b_{6}$, for PE-backed private firms in positive-cash-flow years is negative (but significant only in specification (1)), indicating that PE-backed private firms are more likely than non-PE-backed private firms to offset cash flow in years with positive cash flow. Also as predicted, the incremental coefficient in negative-cash-flow years, $b_{7}$, for PEbacked private firms is significantly positive under specifications (1) and (2) (with coefficients of 2.51, 1.59, and 1.50, and t-values of 2.58, 1.68, and 1.59, respectively), indicating that in negative-cash-flow years, the accruals of PE-backed private firms offset cash flow to a lesser extent than is the case for non-PE-backed private firms (higher positive correlation). Therefore, consistent with $\mathbf{H 2}$, earnings reporting in the pre-IPO period are of higher quality for PE-backed private firms than for non-PE-backed private firms. These results are consistent with the prediction that the involvement of PE sponsors induces higher quality earnings reporting. As indicated in Table 7, however, these results no longer hold in the post-IPO period. ${ }^{41}$

That the coefficients of the inverse Mills' variables (lambda) are significant in neither the pre- nor post-IPO period under both regression models, (3) and (4), suggests the absence of significant endogeneity problems. ${ }^{42}$

Untabulated analyses further reveal that the results of both conservatism regression models, (3) and (4), hold for the comparison of both majority- and minority-PE-owned firms versus management-owned firms. ${ }^{43}$

\footnotetext{
${ }^{41}$ As was discussed in section II above, prior literature finds that publicly listed firms report more conservatively than private firms to accommodate shareholder demand for higher quality earnings reporting and reduce shareholder litigation costs (Skinner 1997, Givoly at al. 2007b). Because these incentives exist as soon as firms are publicly listed, regardless of the initial controlling party, they can increase timely loss recognition among non-PE-backed firms as well, and thereby reduce the differences between them and PE-backed firms in the post-IPO period.

${ }^{42}$ If firms select PE financing based on either expected changes in operating income or expected accruals, the dummy variable PE is endogenous. It is unlikely that a change in operating income will change regression (3) because the PE financing decision is unlikely to involve the change in operating income in a single year. It is more likely in the accruals regression, because it is specified on levels (for further discussion, see Ball and Shivakumar 2005).

${ }^{43}$ I re-estimated the conservatism regression models (3) and (4) with six dummy variables, one for each industry, as defined in Table 2 . The results were qualitatively the same (untabulated).
} 


\section{Results: Abnormal Returns and Financial Performance}

Table 8, Panel A, which reports the results of both size-and-book-to-market-adjusted buy-and-hold returns and financial performance analyses, shows the abnormal returns (between one year and five years) to be significantly higher for firms majority-owned than for firms minority-owned by PE sponsors. ${ }^{44}$ For example, the mean of one-year abnormal returns for firms majority-owned by PE sponsors is $19.1 \%$ (median of $8.8 \%$ ), but the mean for firms minorityowned by PE sponsors is $-9.3 \%$ (median of $-18.3 \%$ ). This difference of $28.5 \%$ (27.1\%) is significant at the 0.01 level for the medians. In the one-year and three-year periods after the IPO, the median returns for firms majority-owned by PE sponsors are also significantly higher than for management-owned firms. Firms minority-owned by PE sponsors have the lowest abnormal returns in the one-, three-, and five-year periods (for the five-year period, their abnormal return is significantly lower than that of management-owned firms).

Table 8, Panel A documents that firms minority-owned by PE sponsors also have the lowest post-IPO financial performance. In particular, they have the lowest (but not statistically significant) industry adjusted ROA and market-to-book ratios (statistically significant for one and three years) as well as the highest percentage of post-IPO delistings. Management-owned firms, on the other hand, have the highest (but not statistically significant) industry adjusted ROA and market-to-book ratios (statistically significant for the one- and three-year periods), and, consistent with the findings in Table 5, the highest level of abnormal accruals in the five years pre-IPO.

Table 8, Panel B reports, separately for the different ownership groups, the results of the Fama-French three factor calendar time portfolio regressions (5). Consistent with the finding

\footnotetext{
${ }^{44}$ The use of other benchmarks, such as the value-weighted market return index or S\&P composite index, yields qualitatively similar results. The results are also qualitatively the same when I use cumulative abnormal returns.
} 
above, Panel B indicates that firms minority-owned by PE sponsors have the lowest average monthly abnormal returns in the one- and three-year periods (as captured by the estimate of the intercept), firms majority-owned by PE sponsors, the highest average monthly abnormal returns.

Taken together, and consistent with $\mathbf{H 3}$, these results suggest that firms majority-owned by PE sponsors have higher abnormal returns than firms owned by management despite their lower financial performance. These results can be attributed to the PE sponsors' higher earnings quality (less engagement in upward earnings management and timelier loss recognition) and capacity for tighter monitoring and control, both pre- and post-IPO. The poor abnormal returns of firms minority-owned by PE sponsors can be attributed to their poor financial performance and the lesser degree of monitoring and control exercised by owners of minority stakes (as indicated in Table 4; see the discussion in the following Additional Results section).

\section{Additional Results}

\section{PE Sponsor Ownership Stake (Majority versus Minority)}

Higher ownership stakes by PE sponsors can contribute to tighter monitoring (Cao 2007), which is expected to be associated with better earnings quality, financial performance, and abnormal returns (see the discussion in section II). Furthermore, post-IPO performance has strong wealth implications, especially for PE sponsors that hold large ownership stakes before and after an IPO (Cao and Lerner 2006). I therefore expect firms that are majority-owned by PE sponsors to outperform firms that are minority-owned by PE sponsors. ${ }^{45}$

\footnotetext{
${ }^{45}$ Alternatively, because higher financial reporting quality is costly, if the tighter monitoring associated with largestake PE ownership substitutes for earnings quality, earnings quality would be expected to decline with higher ownership stakes (Beuselinck and Manigart 2005). Due to their reputation concerns, PE sponsors are expected to acquire minority stakes only in firms that have better corporate governance in place. Furthermore, if going public is a value maximizing decision (Zingales 1995), PE sponsors would be hypothesized to take firms public when the value added by ownership concentration no longer outweighs the monitoring cost, in which case pre-IPO PE sponsor-ownership and post-IPO performance would be negatively associated (Cao 2007).
} 
Untabulated analyses reveal no significant differences in earnings management between firms that are majority-owned and those that are minority-owned by PE sponsors (consistent with the results reported in Table 5, Panel A), and only weak evidence that firms that are majorityowned by PE sponsors report more conservatively than firms that are minority-owned by PE sponsors.

Untabulated analyses further reveal that, when I control for the reduction in ownership stake after the IPO (on both an absolute and a relative basis, and for both PE-backed and non-PEbacked firms), all results remain qualitatively similar.

\section{PE Sponsor Size (Capital under Management)}

Because more firms that are majority owned by PE sponsors are owned by large PE sponsors (those with greater capital under management; see the discussion in section IV), I need to disentangle the influence of ownership stake (majority versus minority) and PE sponsor size, which was identified as the most appropriate proxy for PE sponsor reputation (Cao and Lerner 2006). Overall, I expect firms with more reputable owners to establish better governance and have tighter monitoring, which are expected to be associated with better earnings quality and financial performance in the post-IPO period (Wongsunwai 2007, Ivanov et al. 2008). Cao and Lerner (2006) attribute superior post-IPO returns earned by firms with larger PE sponsors to these repeated players' concern for their reputations. ${ }^{46}$

Untabulated analyses yield only weak evidence that firms owned by large PE sponsors have higher earnings quality - that is, engage in less upward earnings management (only in the pre-IPO period) and report more conservatively—than firms owned by small PE sponsors.

\footnotetext{
${ }^{46}$ Smaller PE sponsors, on the other hand, might have greater need of external financing and so be more strongly motivated to increase the quality of their reported earnings in order to be able to secure cheaper public debt (Bharath et al. 2008).
} 
Table 9, Panel A further reports the results of the abnormal returns as well as financial performance analyses for firms owned by large PE sponsors relative to firms owned by small PE sponsors. Overall, abnormal returns and industry adjusted ROA are significantly higher for firms owned by large PE sponsors. These firms also have a lower percentage of delisting. The results of the market-to-book ratios are mixed. Table 9, Panel B reports the results of the Fama-French three factor calendar time portfolio regressions (5). Consistent with the finding above, firms that are owned by larger PE sponsors have higher average monthly abnormal returns. Taken together, these results indicate that lower engagement in pre-IPO earnings management, together with the ability of large PE sponsors to provide a higher level of monitoring and support, lead to better long-run financial and market-adjusted performance for firms owned by larger PE sponsors.

\section{$\underline{\text { Listing Status }}$}

To gain insight into the influence of private and public listing status, I compare for a given ownership structure financial practices before and after the IPO.

Stock-price penalties and the use of equity-based compensation are strong incentives for managers of U.S. public firms to manage earnings upward (Givoly et al. 2007b). This pattern is consistent with the view that the opportunity to manipulate stock price is a motive for earnings management (Jensen 2005). Moreover, all firm-year observations in my sample, both pre- and post-IPO, are subject to identical financial reporting regulations. But because pre-IPO firms are more closely held, many shareholders have "inside information" and therefore less need to rely on financial statements, and the quality of financial reporting is therefore predicted to be lower in the pre-IPO period (Ball and Shivakumar 2005). Timelier loss recognition is also associated with 
lower shareholder litigation costs (Skinner 1997), which creates an additional incentive for postIPO public firms to recognize losses in a more timely manner.

Consistent with these predictions, and with the findings of Givoly at al. (2007b) and Ball and Shivakumar (2005), untabulated analyses reveal that post-IPO firms have greater upward earnings management and report more conservatively than pre-IPO firms, regardless of the initial controlling party.

\section{ROBUSTNESS CHECKS}

\section{Transition Periods}

In untabulated analyses, I identify specific earnings-management incentives that arise for firms engaged in "going private" (public to private) transactions such as LBOs and MBOs as well as in other contexts such as M\&A and bankruptcy.

Overall, my findings are consistent with the results of prior literature. First, I document lower unexpected discretionary accruals in the two years prior to an MBO transaction. This is consistent with managers' incentive to act in their own financial interest and influence firm price in their favor (DeAngelo 1986, Perry and Williams 1994, Wu 1997, and Marquardt and Wiedman 2004). Second, I find higher unexpected discretionary accruals and growth in net operating assets in the two years prior to an LBO. These results are consistent with entrepreneurs' incentive to manage earnings upward prior to PE financing (Beuselinck et al. 2005). Third, I find evidence consistent with upward earnings management by PE-backed public firms in the years prior to an M\&A transaction, consistent with the assumption that these firms can anticipate an acquisition or initiate and plan for a sale and are therefore able to manage earnings accordingly (Erickson and Wang 1999). Finally, I find evidence of downward earnings 
management by PE-backed public firms in the two years prior to a bankruptcy filing relative to prior years. This result is consistent with the incentive of managers, especially in public firms, to avoid the threat of lawsuits by stakeholders (Rosner 2003). When I remove observations during these transition periods, the results are qualitatively similar.

\section{Restructuring Activities}

Renneboog and Simons (2005) argue that PE sponsors can create the "stronger incentive alignment with a focus on performance and value, the reduction in wasting corporate resources, and the improved monitoring capabilities embedded in the governance structure of an LBO." PEbacked firms, therefore, especially in the pre-IPO period, might be involved in more restructuring activities than non-PE-backed firms, which might affect the results of this study.

I identify and compare for PE-backed and non-PE-backed firms several proxies for restructuring activities including magnitude of discontinued operations, involvement in M\&A activities, and yearly increase or decrease in assets greater than $50 \%$. This analysis reveals that the involvement of both groups of firms in restructuring activities is not significantly different in the period surrounding an IPO. When I remove observations during restructuring periods, the results are qualitatively similar.

\section{Underwriter Reputation}

Table 8 indicates that PE-backed firms have significantly higher underwriter reputation and significantly lower pre-IPO abnormal accruals than management-owned firms. The same holds true for firms owned by large PE sponsors relative to firms owned by small PE sponsors (Table 9). Moreover, a significantly higher percentage of firms that are majority owned by PE 
sponsors are also owned by large PE sponsors, and vice versa. To untangle the influence of these factors and verify that the abnormal return results are not driven by them, I further control for underwriter reputation, pre-IPO abnormal accruals, and PE sponsor size and ownership stake (when applicable). The main abnormal return results are qualitatively similar. ${ }^{47}$

\section{SUMMARY AND CONCLUSIONS}

In this paper, I explore for a unique sample of U.S. private firms with public debt whether ownership structure, that is, being PE-backed or non-PE-backed, affects earnings management, conservatism, and post-IPO performance in the period surrounding an IPO. In addition, for the sub-group of PE-backed firms, I examine the association between the PE sponsor's ownershipstake and size and the firm's earnings quality and performance.

Consistent with my predictions, I find that the presence of and monitoring by sophisticated PE sponsors restrains upward earnings management and induces a higher frequency of timely loss recognition, both pre- and post-IPO. I further find that majority ownership by a PE sponsor is associated with better stock price performance relative to management-owned firms, and that larger PE sponsor size is positively associated with both better long-term financial and stock price performance when a firm goes public. These results can be attributed to less upward earnings management, more timely loss recognition, and tighter monitoring and control by PE sponsors, both pre- and post-IPO. Firms minority-owned by PE sponsors, on the other hand, have worse long-term financial and stock price performance in the years following an IPO than management-owned firms because of the lesser ability of these PE sponsors to control and monitor.

\footnotetext{
${ }^{47}$ Specifically, for each period I run the following regressions: Abnormal_Returns $\mathrm{t}_{\mathrm{t}}=\mathrm{a}_{0}+\mathrm{a}_{1} *$ Dummy_Ownership + $\mathrm{a}_{2} *$ Underwriter_Reputation $+\mathrm{a}_{3} *$ Avg_Pre-IPO_UTACC $+\mathrm{a}_{4} *$ Dummy_Large_PE_Sponsor + $\mathrm{a}_{4}{ }^{*}$ Dummy_Majority_PE_Ownership $+\mathrm{e}_{\mathrm{t}}$.
} 
This study has several limitations. Because I focus on private firms with public debt that later file for public listing, I end up with a relatively small sample size (147 firms and 1,070 firm-year observations). To be able to raise public debt, these firms are more likely to be larger and have better earnings quality than other private firms (Bharath et al. 2008). For these reasons, it is unclear whether this sample is representative of the universe of reverse buyouts overall. Potential sample selection bias concerns, however, are mitigated because these limitations apply to both PE-backed and non-PE-backed firms in my sample.

It is worth exploring the incentives for PE-backed and non-PE-backed firms to manage earnings in order to minimize taxes or manipulate bond prices, and the association of both actions with auditor compensation. Comparing PE-backed and non-PE-backed firms in international settings could enhance the results obtained in this study of domestic firms, and shed further light on the effect of institutions on PE-backed and non-PE-backed firms (Leuz 2006). 


\section{REFERENCES}

Aharony, J., Lin, C., and Loeb, M. P., 1993. Initial public offerings, accounting choices, and earnings management. Contemporary Accounting Research 10 (Fall): 61-81.

Ang, J. S., and Brau, J. C., 2002. Firm transparency and the costs of going public. The Journal of Financial Research 1 (Spring): 1-17.

Ball, R., Kothari, S. P., and Robin, A., 2000. The effect of international institutional factors on properties of accounting earnings. Journal of Accounting and Economics 29 (February): 1-51.

Ball, R., Robin A., and Sadka, G., 2005. Is accounting conservatism due to debt or equity markets? An international test of "contracting" and "value relevance" theories of accounting. Review of Accounting Studies, Forthcoming.

Ball, R., and Shivakumar, L., 2005. Earnings quality in UK private firms: Comparative loss recognition timeliness. Journal of Accounting and Economics 39 (February): 83-128.

Ball, R., and Shivakumar, L., 2006a. The role of accruals in asymmetrically timely gain and loss recognition. Journal of Accounting Research 44 (May): 207-242.

Ball, R., and Shivakumar, L., 2006b. Earnings quality at initial public offerings. Working Paper, University of Chicago and London Business School.

Basu, S., 1997. The conservatism principle and asymmetric timeliness of earnings. Journal of Accounting and Economics 24 (December): 3-37.

Basu, S., Hwang, L., and Jan, C., 2001. Differences in conservatism between Big Eight and non-Big Eight auditors. Working Paper, Baruch College.

Beatty, A. L., and Harris, D. G., 1998. The effects of taxes, agency costs and information asymmetry on earnings management: A comparison of public and private firms. Review of Accounting Studies 3 (December): 299-326.

Beatty, A. L., Ke, B., and Petroni, K. R., 2002. Earnings management to avoid earnings declines across publicly and privately held banks. The Accounting Review 77 (July): 547-570.

Beuselinck, C. A. C., Deloof, M., and Manigart, S., 2005. Earnings quality and private equity investments. Working Paper, Ghent University and University of Antwerp.

Beuselinck, C. A. C., and Manigart, S., 2005. Financial reporting quality in private-equity-backed companies: The impact of ownership concentration. Working Paper, Ghent University and Tilburg University.

Bharath, S. T., Sunder, J., and Sunder, S. V., 2008. Accounting quality and debt contracting. The Accounting Review 83 (January): 1-28.

Bruton, G. D., Keels J. K., and Scifres, E. L., 2002. Corporate restructuring and performance: An agency perspective on the complete buyout cycle. Journal of Business Research 55 (September): 709-724. 
Cadman, B., and Sunder J., 2007. Investor myopia and CEO horizon incentives. Working Paper, Kellogg School of Management.

Cai, N., 2002. Two essays in finance: The pricing of corporate straight-debt IPOs; The pricing of equity IPOs that follow debt public offerings. Dissertation, University of Houston.

Cao, J., 2007. What role do buyout sponsors play when leveraged buyouts go public? Working paper, Boston College.

Cao, J., and Lerner, J., 2006. The performance of reverse leveraged buyouts. Working Paper, Boston College and Harvard University.

Carter, R. B., Dark, F. H., and Singh, A. K., 1998. Underwriter reputation, initial returns, and the long-run performance of IPO stocks. Journal of Finance (February): 285-311.

Chou D. W., Gombola, M., and Liu, F. Y., 2006. Earnings management and stock performance of reverse leveraged buyouts. Journal of Financial and Quantitative Analysis 41 (June): 407-437.

Cohen, D. A., and Langberg, N. S., 2005. From private to public: Venture-capital financing and the informativeness of earnings. Working Paper, University of Southern California and University of Houston.

Cornett, M. M., Marcus, A. J., Saunders, A., and Tehranian, H., 2005. Earnings management, corporate governance, and true financial performance. Working Paper, Southern Illinois University, Boston College, and New York University.

Cotter, J. F., and Peck, S. W., 2001. The structure of debt and active equity investors: The case of the buyout specialist. Journal of Financial Economics 59 (January): 101-147.

CRSP (Center for Research in Security Prices), 2001. CRSP delisting returns (April), University of Chicago Graduate School of Business Web site, http://www.crsp.chicagogsb.edu/resources/files/crsp_white_paper_delist_returns.pdf, accessed June 3, 2007.

Darrough, M., and Rangan, S., 2005. Do insiders manipulate earnings when they sell their shares in an initial public offering? Journal of Accounting Research 43 (March): 1-33.

DeAngelo, E. L., 1986. Accounting numbers as market-valuation substitutes: A study of management buyouts of public stockholders. The Accounting Review 41 (July): 400-420.

Dechow, P. M., Kothari, S. P., and Watts, R. L., 1998. The relation between earnings and cash flows. Journal of Accounting and Economics 25 (May): 133-168.

Degeorge, F., and Zeckhauser, R., 1993. The reverse LBO decision and firm performance: Theory and evidence. Journal of Finance 48 (September): 1323-1348.

Erickson, M., and Wang, S., 1999. Earnings management by acquiring firms in stock-for-stock mergers. Journal of Accounting and Economics 27 (April): 149-176.

Fama, E. F., and French, K. R., 1993. Common risk factors in the returns on stocks and bonds. Journal of Financial Economics 33 (February): 3-56. 
Fan, Q., 2007. Earnings management and ownership retention for initial public offering firms: Theory and evidence. The Accounting Review 82 (January): 27-64.

Field, L.C., and Karpoff, J., 2002. Takeover defenses of IPO firms. Journal of Finance 57 (October): 1857-1889.

Francis, J., LaFond, R. Z., Olsson, P., and Schipper, K., 2005. The market pricing of accruals quality. Journal of Accounting and Economics 39 (June): 295-327.

Fraser-Sampson, G., 2007. Private equity as an asset class. Chichester, West Sussex, England: John Wiley \& Sons, Ltd.

Givoly, D., Hayn, C., and Natarajan, A., 2007a. Measuring reporting conservatism. The Accounting Review 82 (January): 65-106.

Givoly, D., Hayn, C., and Katz, S., 2007b. Does public ownership of equity improve earnings quality? Working Paper, Penn State University, UCLA, and Harvard University.

Gompers, P. A., 1995. Optimal investment, monitoring and the staging of venture capital. Journal of Finance 50 (December): 1461-1489.

Gompers, P. A., Ishii, J., and Metrick, A., 2003. Corporate governance and equity prices. Quarterly Journal of Economics 118 (February): 107-155.

Hand, J. R. M., 2005. The value relevance of financial statements in the venture-capital market. The Accounting Review 80 (April): 613-648.

Haw, I., Hu, B., Hwang, L., and Wu, W., 2004. Ultimate ownership, income management, and legal and extra-legal institutions. Journal of Accounting Research 42 (May): 423-462.

Heckman, J. J., 1979. Sample selection bias as a specification error. Econometrica 47 (January): 153-162.

Hochberg Y., 2006. Venture capital and corporate governance in the newly public firm. Working Paper, Northwestern University.

Holthausen R. W., and Larcker, D. F., 1996. The financial performance of reverse leveraged buyouts. Journal of Financial Economics 42 (November): 293-332.

Hribar, P., and Collins, D. W., 2002. Errors in estimating accruals: Implications for empirical research. Journal of Accounting Research 40 (March): 105-134.

Ivanov, V. I., Krishnan, C. N. V., Masulis, R. W., and Singh, A. K., 2008. Does venture capital reputation matter? Evidence from subsequent IPOs. Working Paper, University of Kansas, Case Western Reserve University, and Vanderbilt University.

Jensen, M. C., 2005. Agency cost of overvalued equity. Financial Management 34 (Spring): 5-19.

Jones, J., 1991. Earnings management during import relief investigations. Journal of Accounting Research 20 (Autumn): 192-228. 
Kaplan, S. N., 1991. The staying power of leveraged buyouts. Journal of Financial Economics 29 (October): 287-314.

Kaplan, S. N., and Strömberg, P., 2003. Financial contracting theory meets the real world: An empirical analysis of venture-capital contracts. Review of Economic Studies 70 (April): 281-315.

Klein, A. and Zur, E., 2007. Entrepreneurial shareholder: Hedge funds and other private investors. Forthcoming in the Journal of Finance.

Kothari, S. P., Leone, A. J., and Wasley, C. E., 2005. Performance-matched discretionary accrual measures. Journal of Accounting and Economics 39 (February): 163-197.

Lerner, J., 1995. Venture capitalists and the oversight of private firms. Journal of Finance 50 (March): 301-318.

Leuz, C., 2006. Cross-listing, bonding, and firms' reporting incentives: A discussion of Lang, Raedy, and Wilsom (2006). Journal of Accounting and Economics 42 (October): 285-299.

Leuz, C., Nanda, D., and Wysocki, P., 2003. Earnings management and investor protection: An international comparison. Journal of Financial Economics 69 (September): 505-527.

Marquardt, C. A., and Wiedman, C. I., 2004. How are earnings managed? An examination of special accruals. Contemporary Accounting Research 21 (Summer): 461-491.

Mikhail, M., 1999. Coordination of earnings, regulatory capital and taxes in private and public companies. Working Paper, Massachusetts Institute of Technology.

Moeller, S., Schlingemann F., and Stulz, R. M., 2004. Firm size and the gains from acquisitions. Journal of Financial Economics 73 (August): 201-228.

Morsfield, G. S., and Tan, C., 2006. Do venture capitalists influence the decision to manage earnings in initial public offerings? The Accounting Review 81 (October): 1119-1150.

Nissim, D., and Penman, S. H., 2003. Financial statement analysis of leverage and how it informs about profitability and price-to-book ratios. Review of Accounting Studies 8 (December): 531-559.

Penman, S., and Zhang, X., 2004. Modeling sustainable earnings and P/E ratios with financial statement information. Working Paper, Columbia University and University of California, Berkeley.

Perry, S. E., and Williams, T. H., 1994. Earnings management preceding management buyout offers. Journal of Accounting and Economics 18 (March): 157-179.

Renneboog, L., and Simons, T., 2005. Public-to-private transactions: LBOs, MBOs, MBIs, and IBOs. Working Paper, Tilburg University and McKinsey \& Co., Inc. (Amsterdam office).

Rosner, R., 2003. Earnings manipulation in failing firms. Contemporary Accounting Research 20 (Summer): 361-408.

Sahlman, W. A., 1990. The structure and governance of venture-capital organizations. Journal of Financial Economics 27 (December): 473-521. 
Shumway, T., and Warther, A. V., 1999. The delisting bias in CRSP's Nasdaq data and its implications for the size effect. Journal of Finance 54 (December): 2361-2379.

Skinner, D. J., 1997. Earnings disclosures and stockholder lawsuits. Journal of Accounting and Economics 23 (November): 249-282.

Teoh, S. H., Welch, I., and Wong, T. J., 1998a. Earnings management and the long-run market performance of initial public offerings. The Journal of Finance 53 (December): 1935-1974.

Teoh, S. H., Welch, I., and Wong, T. J., 1998b. Earnings management and the underperformance of seasoned equity offerings. Journal of Financial Economics 50 (October): 63-99.

Teoh, S. H., Wong, T. J., and Rao, G., 1998. Are accruals during initial public offerings opportunistic? Review of Accounting Studies 3 (December): 175-208.

Wongsunwai, W., 2007. Does venture quality affect corporate governance? Working Paper, Northwestern University.

Wright, M., and Robbie, K., 1998. Venture capital and private equity: A review and synthesis. Journal of Business Finance and Accounting 25 (June/July): 521-570.

Wu, Y. W., 1997. Management buyouts and earnings management. Journal of Accounting, Auditing and Finance 12 (Fall): 373-389.

Xie, H., 2001. The mispricing of abnormal accruals. The Accounting Review 76 (July): 357-373.

Xie, B., Davidson, W., and DaDalt, P., 2003. Earnings management and corporate governance: The role of the board and the audit committee. Journal of Corporate Finance 9 (June): 295-316.

Yeo, H. H. G., Tan, M. S. P., Ho, K. W., and Chen, S., 2002. Corporate ownership structure and the informativeness of earnings. Journal of Business Finance and Accounting 29 (September): 1023-1046.

Zingales, L., 1995. Insider ownership and the decision to go public. Review of Economics Studies 62 (July): 425-448. 
Table 1

Sample Selection

Private Firms with Public Debt (1980-2005)

\begin{tabular}{|c|c|c|}
\hline "Potential" private firms with public debt & $\begin{array}{c}\text { No. of Firm- } \\
\text { year } \\
\text { Observations } \\
13,062\end{array}$ & $\begin{array}{c}\text { No. of Firms } \\
\qquad, 3,355\end{array}$ \\
\hline Historical prospectus data ${ }^{b}$ & $(3,233)$ & $(1,242)$ \\
\hline Public firms & $(2,324)$ & $(371)$ \\
\hline Subsidiaries of public firms & $(561)$ & $(102)$ \\
\hline Public spin-offs & (111) & (34) \\
\hline Firms in bankruptcy process & $(295)$ & $(100)$ \\
\hline Firms with no available information & $(1,683)$ & $(344)$ \\
\hline Foreign firms & $(772)$ & (184) \\
\hline IPO year & $(116)$ & $(116)$ \\
\hline Other ${ }^{c}$ & $(737)$ & $(280)$ \\
\hline Subtotal & 3,230 & 582 \\
\hline 1978-1979 Firm-year Observations & $(65)$ & 0 \\
\hline Cooperatives, LPs, and Government-owned Firms & $(355)$ & $(25)$ \\
\hline Private firms with public debt & 2,810 & 557 \\
\hline IPO firms (11 years surrounding the IPO $)^{\mathrm{d}}$ & 1,070 & 147 \\
\hline
\end{tabular}

a The sample of "potential" private firms with public debt covers all firm-year observations on COMPUSTAT for any of the 28 years from 1978 to 2005 that satisfy the following criteria: (1) the firm's stock price at fiscal year end is unavailable; (2) the firm has total debt as well as total revenues exceeding \$1 million; (3) the firm is a separate domestic company, not a subsidiary of another public firm; and (4) the firm has the financial data needed to test the hypotheses for at least two years. I further exclude financial institutions and firms in other regulated industries (SIC codes 6000-6999 and 4800-4900).

${ }^{\mathrm{b}}$ COMPUSTAT reports three years of historical information for public firms that file for initial public offering. This financial information is taken from the prospectus.

c "Other" includes observations of the same firm with different names, firms with no consecutive years of information, firms that have joint ventures and partnerships with public firms, holding companies of public firms, and observations with information available only for the years 1978-1979.

${ }^{\mathrm{d}}$ Firms that are owned by PE sponsors or management and that filed for an initial public offering (IPO). The firmyear observations include the period of five years before and five years after the IPO.

Sources: EDGAR, 10K Wizard, BankruptcyData.com, Hoover's DataBase, Factiva, ProQuest, and LexisNexis. 


\section{Table 2 \\ Descriptive Statistics on Private Firms with Public Debt}

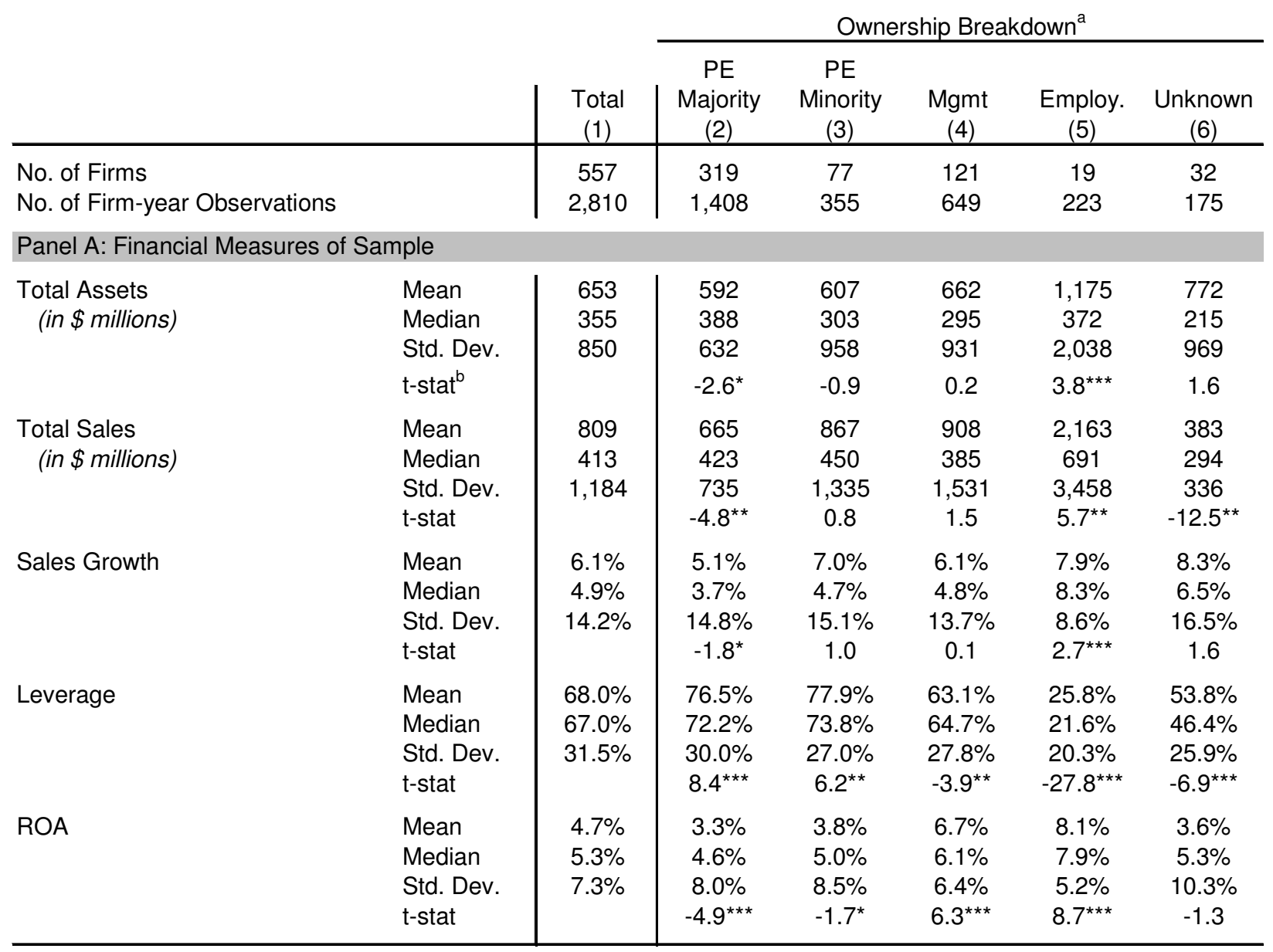

$* * *$ significance at the 0.01 level, $* *$ significance at the 0.05 level, $*$ significance at the 0.10 level.

The distribution of each variable is truncated at the extreme $\pm 1 \%$ values.

${ }^{a}$ Ownership of private equity firms was determined based on the majority or minority ownership. Management ownership was based on the holdings of the founders, top executives, directors, and family members. Employee ownership was based on the holdings of employees including their pension and stock option plans. The "unknown" category generally consists of firms with no available information regarding ownership.

${ }^{b} t$-stat for two-tailed tests of the differences between the specific ownership's financials and the total financials.

\section{Legend:}

Total Assets Total end-of-the-year assets in millions of dollars (COMPUSTAT data item \#6).

Total Sales $\quad$ Sales (net) in millions of dollars (\#12).

Leverage $\quad$ Total debt (\#9+\#34) divided by total assets at end of the year (\#6).

Sales Growth Growth in sales (\#12) from year $\mathrm{t}-1$ to year $\mathrm{t}$.

ROA Net income (\#172) plus net of tax interest expense (\#15) divided by total assets at end of year t-1 (lagged \#6). 
Table 2 (continued)

\section{Descriptive Statistics on Private Firms with Public Debt}

\begin{tabular}{|c|c|c|c|c|c|c|}
\hline & $\begin{array}{c}\text { Total } \\
(1)\end{array}$ & $\begin{array}{c}\mathrm{PE} \\
\text { Majority } \\
(2) \\
\end{array}$ & $\begin{array}{c}\text { PE } \\
\text { Minority } \\
(3) \\
\end{array}$ & $\begin{array}{c}\text { Mgmt } \\
(4)\end{array}$ & $\begin{array}{c}\text { Employ. } \\
(5)\end{array}$ & $\begin{array}{c}\text { Unknown } \\
(6)\end{array}$ \\
\hline No. of Firms & 557 & 319 & 77 & 121 & 19 & 32 \\
\hline No. of Firm-year Observations & 2,810 & 1,408 & 355 & 649 & & \\
\hline \multicolumn{7}{|c|}{ Panel B: Industry Affiliation (two-digit SIC codes) } \\
\hline Mining \& Construction (10-17) & $3.2 \%$ & $2.2 \%$ & $1.3 \%$ & $7.4 \%$ & $5.3 \%$ & -- \\
\hline Manufacturing I (20-29) & $23.9 \%$ & $22.6 \%$ & $27.3 \%$ & $27.3 \%$ & $15.8 \%$ & $21.9 \%$ \\
\hline Manufacturing II (30-39) & $30.3 \%$ & $36.7 \%$ & $23.4 \%$ & $21.5 \%$ & $10.5 \%$ & $28.1 \%$ \\
\hline Transportation \& Public Utilities (40-49) & $3.8 \%$ & $3.4 \%$ & $2.6 \%$ & $2.5 \%$ & $10.5 \%$ & $9.4 \%$ \\
\hline Retail \& Wholesale Trade (50-59) & $21.9 \%$ & $21.0 \%$ & $33.8 \%$ & $19.8 \%$ & $10.5 \%$ & $25.0 \%$ \\
\hline Services & $16.3 \%$ & $14.1 \%$ & $10.4 \%$ & $20.7 \%$ & $42.1 \%$ & $15.6 \%$ \\
\hline Other & $0.5 \%$ & -- & $1.3 \%$ & $0.8 \%$ & $5.3 \%$ & -- \\
\hline \multicolumn{7}{|l|}{ Panel C: S\&P Senior Debt Ranking (\#280) } \\
\hline BBB or Better & $2.9 \%$ & $0.2 \%$ & $2.0 \%$ & $0.3 \%$ & $13.9 \%$ & $22.3 \%$ \\
\hline BB & $9.3 \%$ & $9.4 \%$ & $3.7 \%$ & $13.4 \%$ & $6.3 \%$ & $8.6 \%$ \\
\hline B & $41.6 \%$ & $53.1 \%$ & $52.1 \%$ & $30.8 \%$ & $6.3 \%$ & $13.1 \%$ \\
\hline $\mathrm{C}-\mathrm{CCC}$ & $4.6 \%$ & $5.6 \%$ & $6.5 \%$ & $4.0 \%$ & -- & -- \\
\hline D and Selective Default & 0.3 & $0.2 \%$ & -- & $0.8 \%$ & -- & $0.6 \%$ \\
\hline Not Rated & $41.2 \%$ & $31.4 \%$ & $35.8 \%$ & $50.7 \%$ & $73.5 \%$ & $55.4 \%$ \\
\hline \multicolumn{7}{|c|}{ Panel D: Change in Status during the Sample Period } \\
\hline IPO & $28.4 \%$ & $30.1 \%$ & $35.1 \%$ & $19.8 \%$ & $31.6 \%$ & $21.9 \%$ \\
\hline Bankruptcy & $16.2 \%$ & $17.2 \%$ & $19.5 \%$ & $13.2 \%$ & $5.3 \%$ & $15.6 \%$ \\
\hline$M \& A$ & $16.5 \%$ & $16.9 \%$ & $14.3 \%$ & $12.4 \%$ & $21.1 \%$ & $28.1 \%$ \\
\hline Deregistration & $15.6 \%$ & $14.1 \%$ & $6.5 \%$ & $28.1 \%$ & $5.3 \%$ & $6.3 \%$ \\
\hline Total percent of firms that changed value & $76.7 \%$ & $78.4 \%$ & $75.3 \%$ & $73.6 \%$ & $63.2 \%$ & $71.9 \%$ \\
\hline \multicolumn{7}{|l|}{ Panel E: Size of PE Sponsor Firms ${ }^{a}$} \\
\hline Tier 1 & $3.1 \%$ & $6.0 \%$ & $0.8 \%$ & & & \\
\hline Tier 2 & $7.4 \%$ & $13.1 \%$ & $6.5 \%$ & & & \\
\hline Tier 3 & $4.8 \%$ & $9.2 \%$ & $1.1 \%$ & & & \\
\hline Other & $84.7 \%$ & $71.6 \%$ & $91.5 \%$ & & & \\
\hline
\end{tabular}

${ }^{a}$ PE sponsors are ranked according to total investment (in \$US) during the years 1980-2005.

Tier 1 includes: Warburg Pincus, Carlyle Group, and KKR.

Tier 2 includes: Apax, Blackstone, Goldman Sachs, J.P. Morgan, Welsh Carson Anderson \& Stone, and Hicks Muse Tate \& Furst.

Tier 3 includes: 3 i Group, Bain Capital, Thomas H. Lee, Morgan Stanley, and Cinven.

Source: Thomson Financials, VentureXpert. 
Table 3

Descriptive Statistics Pre-IPO and Post-IPO

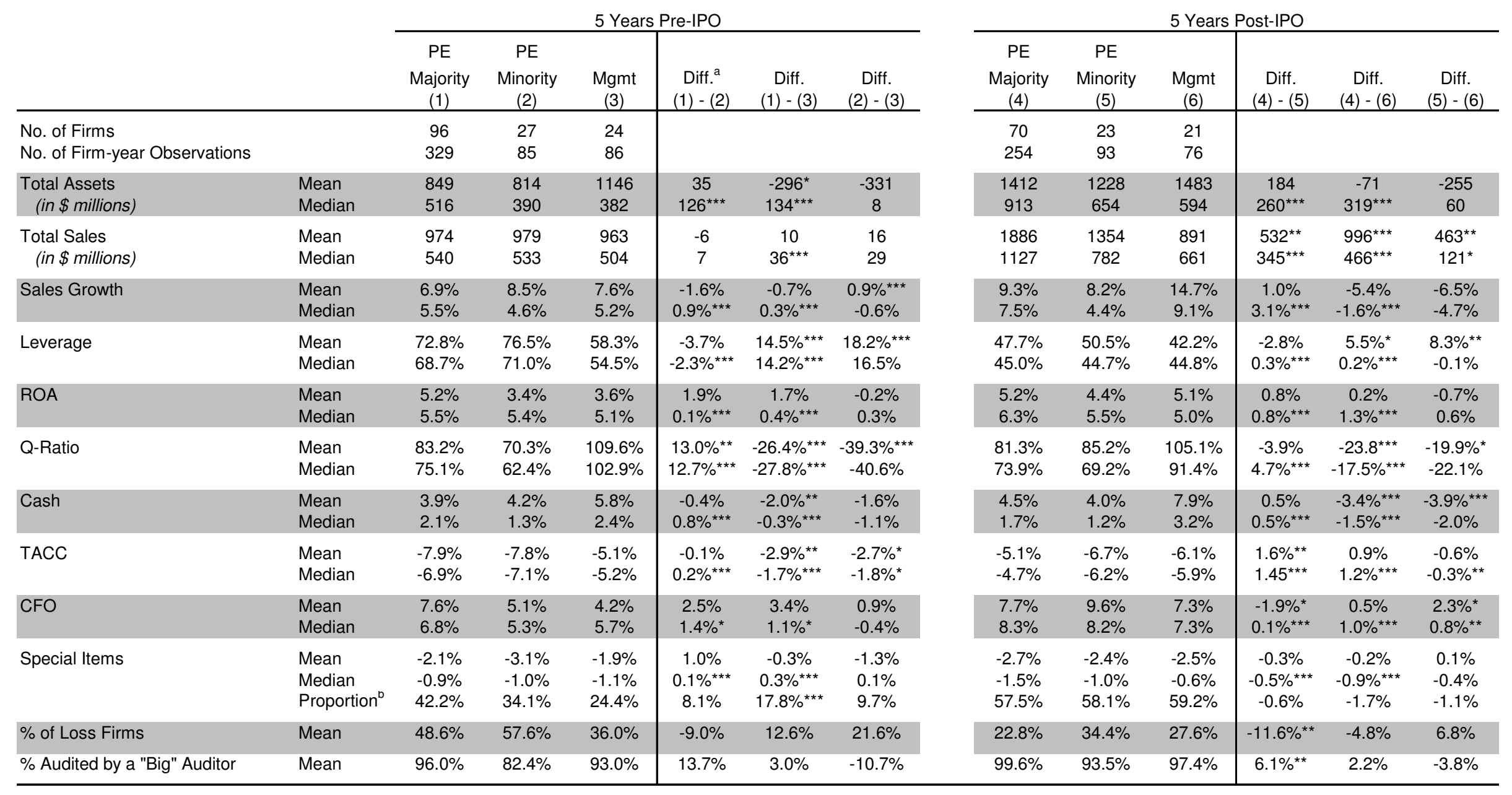

$* * *$ significance at the 0.01 level, $* *$ significance at the 0.05 level, $*$ significance at the 0.10 level.

The distribution of each variable is winsorized at the extreme $\pm 1 \%$ values.

${ }^{a}$ Differences in means are tested for significance using a two-tailed t-test; differences in medians are tested for significance using a two-tailed Wilcoxon signed rank test. 


\section{Table 3 (Continued) \\ Descriptive Statistics Pre-IPO and Post-IPO}

${ }^{\mathrm{b}}$ Proportion is calculated as the number of observations that reported special items divided by the total number of observations. Statistical significance is assessed using the t-test for differences in proportions.

\section{Legend:}

Total Assets Total Sales

Leverage

Sales Growth

ROA

Q-Ratio

Cash

TACC

CFO

Special Items

Loss Firms

Audited by

"Big" Auditor
Total end-of-the-year assets in millions of dollars (COMPUSTAT data item \#6).

Sales (net) in millions of dollars (\#12).

Total debt (\#9+\#34) divided by total assets at end of the year (\#6).

Growth in sales (\#12) from year $t-1$ to year $t$.

Net income (\#172) plus net of tax interest expense (\#15) divided by total assets at end of year t-1 (lagged \#6).

Cash and short-term investment (\#1) plus total receivables (\#2) divided by current liabilities (\#5).

Cash and short-term investment (\#1) divided by total assets at end of year $\mathrm{t}(\# 6)$.

Total accruals divided by total assets at end of year $\mathrm{t}-1$ (lagged \#6). For year $>=1988$ : total accruals [income before extraordinary items (SCF) (\#123) - net cash flow from operating activities (\#308) + extraordinary items and discounted operations (SCF) (\#124)] divided by total assets at end of year $\mathrm{t}-1$ (lagged \#6). For year<1988: [change in current assets during period $\mathrm{t}(\# 4)$ - change in current liabilities during period $\mathrm{t}$ (\#5) change in cash and cash equivalents during period $\mathrm{t}(\# 1)$ + change in current maturities of long-term debt and other short-term debt included in current liabilities during period $\mathrm{t}(\# 34)$ - depreciation and amortization expense during period $\mathrm{t}(\# 125)$ ].

In addition, I eliminated firm-year observations with the following "non-articulation" events:

firm-year observations in which a company is involved in a merger or acquisition (\#AFTNT35 code \#1); firm-year observations in which a company reports "discontinued operations" greater than $\$ 10,000$ (\#66); and firm-year observations in which a company reports a gain or loss on foreign currency translations greater than $\$ 10,000$ (\#150) (Hribar and Collins 2002).

Cash flow from operations divided by total assets at the end of year $t-1$. For year $>=1988$ : net cash flow from operating activities (\#308) divided by total assets at end of year $\mathrm{t}-1$ (lagged \#6).

For year <1988: [funds from operations (\#110) - change in current assets during period $\mathrm{t}(\# 4)+$ change in cash and cash equivalent during period $\mathrm{t}(\# 1)+$ change in current liabilities during period $\mathrm{t}(\# 5)$ - change in current maturities of long-term debt and other short-term debt included in current liabilities during period t (\#34)]. All variables are divided by total assets at end of year t-1 (lagged \#6) (Xie 2001).

Special items (\#17) divided by total assets at end of year $\mathrm{t}-1$ (lagged \#6).

Firms with negative net income (\#172) during year t.

Percentage of firms audited by one of the big national auditing firms (\#149). 
Table 4

\section{Corporate Governance}

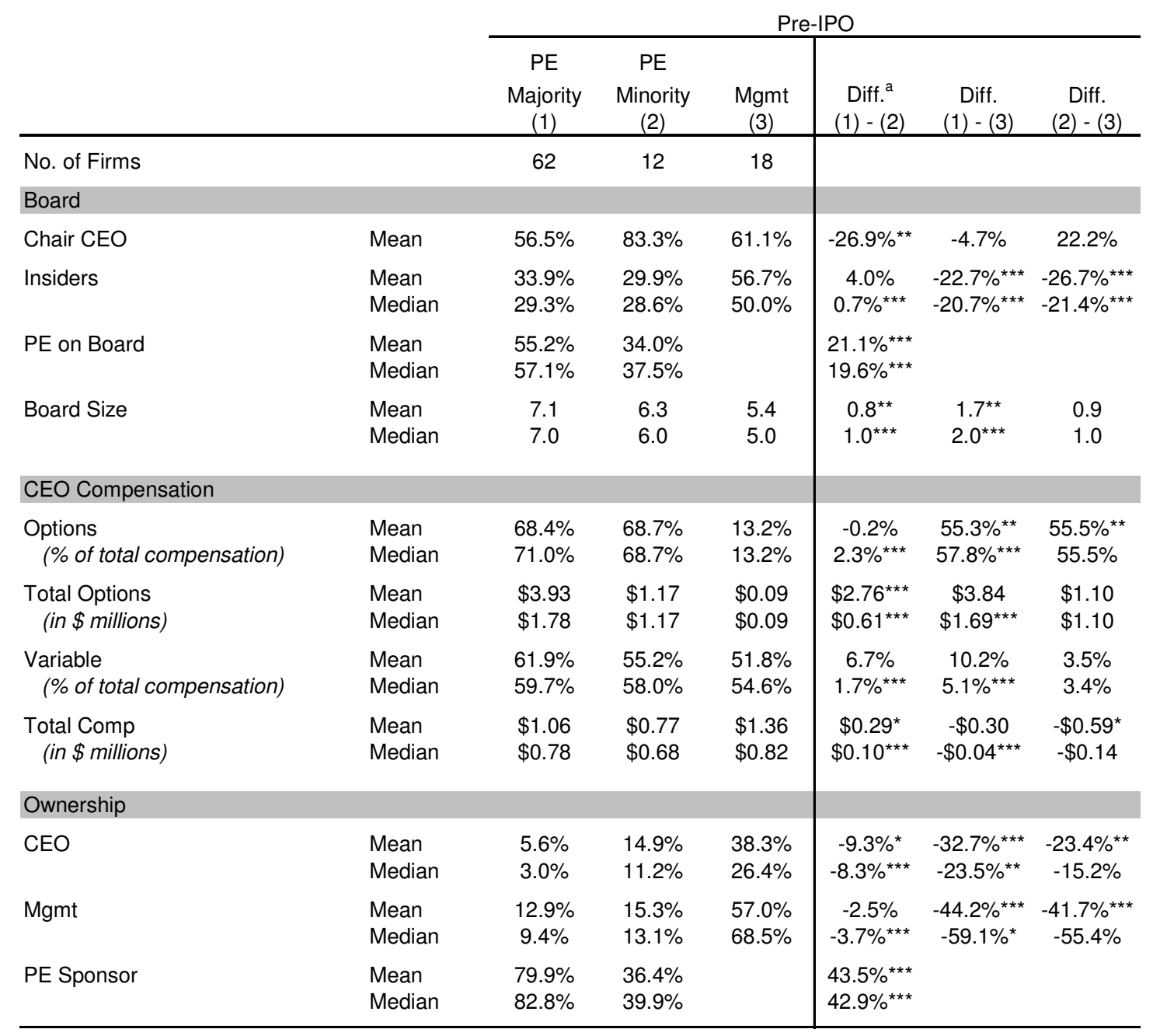

\begin{tabular}{|c|c|c|c|c|c|}
\hline \multicolumn{6}{|c|}{ Post-IPO } \\
\hline PE & PE & & & & \\
\hline $\begin{array}{c}\text { Majority } \\
(4)\end{array}$ & $\begin{array}{l}\text { Minority } \\
\text { (5) }\end{array}$ & $\begin{array}{l}\text { Mgmt } \\
(6)\end{array}$ & $\begin{array}{l}\text { Diff. } \\
(4)-(5)\end{array}$ & $\begin{array}{l}\text { Diff. } \\
(4)-(6)\end{array}$ & $\begin{array}{c}\text { Diff. } \\
(5)-(6)\end{array}$ \\
\hline 62 & 12 & 18 & & & \\
\hline $54.8 \%$ & $91.7 \%$ & $61.1 \%$ & $-36.8 \% * * *$ & $-6.3 \%$ & $30.6 \%$ ** \\
\hline $25.3 \%$ & $27.6 \%$ & $37.4 \%$ & $-2.4 \%$ & $-12.1 \% \%^{* * *}$ & $-9.8 \%$ ** \\
\hline $22.2 \%$ & $28.6 \%$ & $40.0 \%$ & $-6.3 \%$ *** & $-17.8 \% \%^{* \star *}$ & $-11.4 \%$ * \\
\hline $50.3 \%$ & $29.4 \%$ & & $20.9 \%$ *** & & \\
\hline $50.0 \%$ & $31.0 \%$ & & $19.0 \% \%^{\star * *}$ & & \\
\hline 8.2 & 6.3 & 6.6 & $1.8^{\star \star *}$ & $1.5^{\star * \star}$ & -0.3 \\
\hline 8.0 & 7.0 & 6.5 & $1.0^{\star \star *}$ & $1.5^{\star * *}$ & 0.5 \\
\hline $69.9 \%$ & $65.7 \%$ & $46.9 \%$ & $4.2 \%$ & $23.0 \%$ * & $18.8 \%$ \\
\hline $74.3 \%$ & $66.1 \%$ & $43.7 \%$ & $8.2 \%^{* * *}$ & $30.6 \%$ *** & $22.4 \%$ \\
\hline$\$ 8.41$ & $\$ 3.36$ & $\$ 0.65$ & $\$ 5.04$ & $\$ 7.76^{* * *}$ & $\$ 2.72$ \\
\hline$\$ 2.74$ & $\$ 1.55$ & $\$ 0.39$ & $\$ 1.18^{* \star \star}$ & $\$ 2.34^{\star \star *}$ & $\$ 1.16$ \\
\hline $73.8 \%$ & $69.0 \%$ & $45.4 \%$ & $4.8 \%$ & $28.4 \%$ *** & $23.6 \%$ ** \\
\hline $82.5 \%$ & $69.8 \%$ & $50.2 \%$ & $12.7 \%$ *** & $32.3 \%$ *** & $19.6 \%$ \\
\hline$\$ 1.62$ & $\$ 1.09$ & $\$ 0.77$ & $\$ 0.53$ & $\$ 0.84^{* *}$ & $\$ 0.32$ \\
\hline$\$ 0.95$ & $\$ 0.72$ & $\$ 0.60$ & $\$ 0.23^{* * *}$ & $\$ 0.35^{* * *}$ & $\$ 0.12$ \\
\hline $3.2 \%$ & $6.2 \%$ & $15.0 \%$ & $-3.1 \%$ & $-11.8 \%{ }^{*}$ & $-8.8 \%$ \\
\hline $1.9 \%$ & $3.8 \%$ & $8.0 \%$ & $-1.9 \%$ \%** & $-6.1 \%$ *** & $-4.2 \%$ \\
\hline $6.5 \%$ & $12.5 \%$ & $49.6 \%$ & $-6.0 \% *$ & $-43.0 \% * * *$ & $-37.0 \%$ *** \\
\hline $4.6 \%$ & $13.4 \%$ & $51.6 \%$ & $-8.8 \%$ *** & $-47.0 \%$ & $-38.2 \%$ ** \\
\hline $48.9 \%$ & $20.8 \%$ & & $28.0 \%$ *** & & \\
\hline $50.1 \%$ & $20.5 \%$ & & $29.6 \%$ *** & & \\
\hline
\end{tabular}

$* * *$ significance at the 0.01 level, $* *$ significance at the 0.05 level, $*$ significance at the 0.10 level.

${ }^{a}$ Differences in means are tested for significance using a two-tailed t-test; differences in medians are tested for significance using a two-tailed Wilcoxon signed rank test. 


\section{Table 4 (continued) \\ Corporate Governance}

\section{$\underline{\text { Legend: }}$}

Chair CEO Percentage of firms in which the CEO is the chairman of the board of directors.

Insiders $\quad$ Number of directors who serve as executives in the firm divided by total board size.

PE on Board Number of directors who represent PE sponsors divided by total board size.

Board Size Total number of directors on the board of directors.

Options

Total options divided by the sum of the total comp and total options.

Total Options Cumulative value of options distributed to the CEO during her/his tenure as well as the cumulative value of options realized. When the cumulative value was absent, the average value of options distributed during the year was used.

Variable Sum of the total option, bonus, other annual compensation, and other compensation (excluding salary) divided by the total comp and total options. (Note: Variable includes instances in which options were NOT distributed.)

Total Comp Sum of the salary, bonus, other annual compensation, and other compensation.

CEO

Percentage owned by the CEO.

Mgmt

Percentage owned by the management.

PE

Percentage owned by the PE sponsors. 
Table 5

Magnitude of Abnormal Accruals and Growth in Net Operating Assets

Panel A: Univariate Analysis

\begin{tabular}{|c|c|c|c|c|c|c|c|c|c|c|c|c|c|c|c|c|}
\hline \multirow[b]{2}{*}{ Years } & & \multicolumn{3}{|c|}{ PE Majority } & \multicolumn{3}{|c|}{ PE Minority } & \multicolumn{3}{|c|}{ Mgmt } & \multicolumn{2}{|c|}{$\begin{array}{c}\text { Diff. }{ }^{a} \text { PE Majority } \\
\text { v. PE Minority }\end{array}$} & \multicolumn{2}{|c|}{$\begin{array}{c}\text { Diff. PE Majority } \\
\text { v. Mgmt }\end{array}$} & \multicolumn{2}{|c|}{$\begin{array}{c}\text { Diff. PE Minority } \\
\text { V. Mgmt }\end{array}$} \\
\hline & & $\mathrm{N}$ & $\begin{array}{c}\text { UTACC } \\
(1)\end{array}$ & $\begin{array}{c}\text { GNOA } \\
(2) \\
\end{array}$ & $\mathrm{N}$ & $\begin{array}{c}\text { UTACC } \\
(3)\end{array}$ & $\begin{array}{c}\text { GNOA } \\
(4) \\
\end{array}$ & $\mathrm{N}$ & $\begin{array}{c}\text { UTACC } \\
(5)\end{array}$ & $\begin{array}{c}\text { GNOA } \\
(6) \\
\end{array}$ & $\begin{array}{l}\text { UTACC } \\
(1)-(3) \\
\end{array}$ & $\begin{array}{l}\text { GNOA } \\
(2)-(4) \\
\end{array}$ & $\begin{array}{l}\text { UTACC } \\
(1)-(5) \\
\end{array}$ & $\begin{array}{l}\text { GNOA } \\
(2)-(6) \\
\end{array}$ & $\begin{array}{l}\text { UTACC } \\
(3)-(5) \\
\end{array}$ & $\begin{array}{r}\text { GNOA } \\
(4)-(6) \\
\end{array}$ \\
\hline $\begin{array}{l}5 \text { Years } \\
\text { Pre-IPO }\end{array}$ & $\begin{array}{l}\text { Mean } \\
\text { Median }\end{array}$ & 277 & $\begin{array}{l}-3.7 \% \\
-3.5 \%\end{array}$ & $\begin{array}{l}-4.9 \% \\
-3.2 \%\end{array}$ & 69 & $\begin{array}{l}-4.2 \% \\
-2.1 \%\end{array}$ & $\begin{array}{l}-9.6 \% \\
-7.9 \%\end{array}$ & 79 & $\begin{array}{l}-0.3 \% \\
-1.1 \%\end{array}$ & $\begin{array}{l}-0.9 \% \\
-2.9 \%\end{array}$ & $\begin{array}{c}0.5 \% \\
-1.4 \%^{*}\end{array}$ & $\begin{array}{l}4.7 \%^{* *} \\
4.7 \%^{* *}\end{array}$ & $\begin{array}{l}-3.4 \%^{\star \star * *} \\
-2.3 \%^{* * *}\end{array}$ & $\begin{array}{c}-4.0 \% \\
-0.3 \% \text { (*** }\end{array}$ & $\begin{array}{l}-3.9 \%^{* * *} \\
-1.0 \%^{* *}\end{array}$ & $\begin{array}{l}-8.7 \%^{*} \\
-4.9 \%{ }^{* *}\end{array}$ \\
\hline $\begin{array}{l}5 \text { Years } \\
\text { Post-IPO }\end{array}$ & $\begin{array}{l}\text { Mean } \\
\text { Median }\end{array}$ & 206 & $\begin{array}{l}-1.4 \% \\
-0.8 \%\end{array}$ & $\begin{array}{l}-2.1 \% \\
-0.6 \%\end{array}$ & 81 & $\begin{array}{l}-1.4 \% \\
-1.2 \%\end{array}$ & $\begin{array}{l}-0.9 \% \\
-2.9 \%\end{array}$ & 62 & $\begin{array}{l}5.4 \% \\
1.5 \%\end{array}$ & $\begin{array}{l}13.9 \% \\
0.4 \%\end{array}$ & $\begin{array}{l}0.0 \% \\
0.4 \%\end{array}$ & $\begin{array}{l}-1.2 \% \\
2.3 \%\end{array}$ & $\begin{array}{l}-6.8 \%^{*} \\
-2.3 \% \%^{* *}\end{array}$ & $\begin{array}{l}-16.0 \%^{* *} \\
-1.0 \%^{* * *}\end{array}$ & $\begin{array}{l}-6.8 \%^{*} \\
-2.7 \%^{* *}\end{array}$ & $\begin{array}{l}-14.8 \%^{* *} \\
-3.3 \%^{* * *}\end{array}$ \\
\hline $\begin{array}{l}\text { Avg. } 5 \text { Years } \\
\text { Post-IPO }\end{array}$ & $\begin{array}{l}\text { Mean } \\
\text { Median }\end{array}$ & & $\begin{array}{l}-0.3 \% \\
-0.6 \%\end{array}$ & $\begin{array}{l}-1.5 \% \\
-0.8 \%\end{array}$ & & $\begin{array}{l}-1.4 \% \\
-0.2 \%\end{array}$ & $\begin{array}{l}2.3 \% \\
1.2 \%\end{array}$ & & $\begin{array}{l}3.3 \% \\
1.7 \%\end{array}$ & $\begin{array}{c}13.4 \% \\
4.9 \%\end{array}$ & $\begin{array}{r}1.1 \% \\
-0.4 \%\end{array}$ & $\begin{array}{c}-3.7 \% \\
1.2 \%\end{array}$ & $\begin{array}{l}-3.6 \% \\
-2.3 \%{ }^{*}\end{array}$ & $\begin{array}{c}-14.9 \%{ }^{* *} \\
-5.6 \% *\end{array}$ & $\begin{array}{l}-4.7 \% \\
-1.9 \%\end{array}$ & $\begin{array}{c}-11.2 \%{ }^{*} \\
-3.6 \%\end{array}$ \\
\hline-5 & $\begin{array}{l}\text { Mean } \\
\text { Median }\end{array}$ & 32 & $\begin{array}{l}-4.9 \% \\
-4.0 \%\end{array}$ & $\begin{array}{l}6.0 \% \\
-1.5 \%\end{array}$ & 5 & $\begin{array}{l}-8.7 \% \\
-1.3 \%\end{array}$ & $\begin{array}{l}-22.7 \% \\
-15.4 \%\end{array}$ & 12 & $\begin{array}{l}8.8 \% \\
7.1 \%\end{array}$ & $\begin{array}{l}15.8 \% \\
-0.6 \%\end{array}$ & $\begin{array}{c}3.9 \% \\
-2.7 \% * * *\end{array}$ & $\begin{array}{l}28.7 \% \\
14.0 \%\end{array}$ & 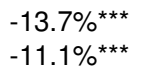 & $\begin{array}{l}-9.8 \% \\
-0.8 \%\end{array}$ & $\begin{array}{l}-17.6 \% \%^{* *} \\
-8.4 \%^{* * *}\end{array}$ & $\begin{array}{l}-38.5 \%{ }^{*} \\
-14.8 \%{ }^{*}\end{array}$ \\
\hline-4 & $\begin{array}{l}\text { Mean } \\
\text { Median }\end{array}$ & 48 & $\begin{array}{l}-3.5 \% \\
-2.8 \%\end{array}$ & $\begin{array}{l}-5.5 \% \\
-2.6 \%\end{array}$ & 11 & $\begin{array}{c}-25.5 \% \\
-2.3 \%\end{array}$ & $\begin{array}{l}86.6 \% \\
-10.0 \%\end{array}$ & 13 & $\begin{array}{l}-3.8 \% \\
-4.0 \%\end{array}$ & $\begin{array}{l}7.0 \% \\
-2.2 \%\end{array}$ & $\begin{array}{c}21.9 \% \\
-0.6 \%\end{array}$ & $\begin{array}{l}-92.1 \% \\
7.4 \%^{*}\end{array}$ & $\begin{array}{l}0.3 \% \\
1.2 \%\end{array}$ & $\begin{array}{l}-12.5 \% \\
-0.4 \%\end{array}$ & $\begin{array}{c}-21.6 \% \\
1.8 \%\end{array}$ & $\begin{array}{l}79.6 \% \\
-7.9 \%\end{array}$ \\
\hline-3 & $\begin{array}{l}\text { Mean } \\
\text { Median }\end{array}$ & 65 & $\begin{array}{l}-4.3 \% \\
-3.1 \%\end{array}$ & $\begin{array}{l}-1.1 \% \\
-6.4 \%\end{array}$ & 18 & $\begin{array}{l}-4.3 \% \\
-0.7 \%\end{array}$ & $\begin{array}{l}-8.0 \% \\
-7.1 \%\end{array}$ & 17 & $\begin{array}{l}-2.0 \% \\
-1.4 \%\end{array}$ & $\begin{array}{l}-5.5 \% \\
-6.4 \%\end{array}$ & $\begin{array}{c}0.0 \% \\
-2.4 \%\end{array}$ & $\begin{array}{c}6.9 \% \\
0.7 \%{ }^{* \star}\end{array}$ & $\begin{array}{c}-2.3 \% \\
-1.7 \% \text { *** }\end{array}$ & $\begin{array}{c}4.4 \% \\
0.0 \%{ }^{* *}\end{array}$ & $\begin{array}{c}-2.3 \% \\
0.8 \%\end{array}$ & $\begin{array}{l}-2.6 \% \\
-0.7 \%\end{array}$ \\
\hline-2 & $\begin{array}{l}\text { Mean } \\
\text { Median }\end{array}$ & 87 & $\begin{array}{l}-4.3 \% \\
-3.7 \%\end{array}$ & $\begin{array}{r}1.4 \% \\
-6.5 \%\end{array}$ & 23 & $\begin{array}{l}-5.9 \% \\
-4.5 \%\end{array}$ & $\begin{array}{l}9.3 \% \\
-5.9 \%\end{array}$ & 20 & $\begin{array}{l}-0.2 \% \\
-1.6 \%\end{array}$ & $\begin{array}{l}-3.8 \% \\
-4.3 \%\end{array}$ & $\begin{array}{c}1.6 \% \\
0.8 \% \text { ** }\end{array}$ & $\begin{array}{l}-7.9 \% \\
-0.7 \%\end{array}$ & $\begin{array}{c}-4.1 \%^{*} \\
-2.0 \%{ }^{* *}\end{array}$ & $\begin{array}{c}5.2 \% \\
-2.2 \%\end{array}$ & $\begin{array}{l}-5.7 \%^{* *} \\
-2.9 \%^{*}\end{array}$ & $\begin{array}{l}13.1 \% \\
-1.6 \%\end{array}$ \\
\hline-1 & $\begin{array}{l}\text { Mean } \\
\text { Median }\end{array}$ & 96 & $\begin{array}{l}-4.3 \% \\
-3.9 \%\end{array}$ & $\begin{array}{r}6.4 \% \\
-3.3 \%\end{array}$ & 27 & $\begin{array}{l}-3.5 \% \\
-5.4 \%\end{array}$ & $\begin{array}{l}5.7 \% \\
-7.9 \%\end{array}$ & 24 & $\begin{array}{c}-0.1 \% \\
1.1 \%\end{array}$ & $\begin{array}{l}-3.8 \% \\
-5.3 \%\end{array}$ & $\begin{array}{c}-0.7 \% \\
1.5 \%\end{array}$ & $\begin{array}{l}0.7 \% \\
4.6 \%\end{array}$ & $\begin{array}{l}-4.1 \% \%^{* *} \\
-5.0 \%{ }^{* * *}\end{array}$ & $\begin{array}{c}10.2 \% \\
2.0 \%\end{array}$ & $\begin{array}{l}-3.4 \% \\
-6.5 \%\end{array}$ & $\begin{array}{r}9.5 \% \\
-2.6 \%\end{array}$ \\
\hline IPO Year & $\begin{array}{l}\text { Mean } \\
\text { Median }\end{array}$ & 84 & $\begin{array}{l}-1.9 \% \\
-1.3 \%\end{array}$ & $\begin{array}{l}5.7 \% \\
0.0 \%\end{array}$ & 24 & $\begin{array}{l}0.5 \% \\
0.5 \%\end{array}$ & $\begin{array}{l}25.1 \% \\
-2.0 \%\end{array}$ & 24 & $\begin{array}{l}7.3 \% \\
1.1 \%\end{array}$ & $\begin{array}{c}365.4 \% \\
12.7 \%\end{array}$ & $\begin{array}{c}-2.4 \% \\
-1.7 \% \text { *** }\end{array}$ & $\begin{array}{c}-19.4 \% \\
2.0 \%\end{array}$ & $\begin{array}{c}-9.2 \% \\
-2.4 \%\end{array}$ & $\begin{array}{l}-359.7 \% \\
-12.7 \%{ }^{*}\end{array}$ & $\begin{array}{l}-6.8 \% \\
-0.6 \%\end{array}$ & $\begin{array}{c}-340.3 \% \\
-14.7 \%\end{array}$ \\
\hline+1 & $\begin{array}{l}\text { Mean } \\
\text { Median }\end{array}$ & 70 & $\begin{array}{l}0.6 \% \\
0.3 \%\end{array}$ & $\begin{array}{c}11.9 \% \\
0.0 \%\end{array}$ & 23 & $\begin{array}{l}0.5 \% \\
0.2 \%\end{array}$ & $\begin{array}{l}-0.5 \% \\
-2.4 \%\end{array}$ & 21 & $\begin{array}{l}1.1 \% \\
-1.1 \%\end{array}$ & $\begin{array}{c}46.9 \% \\
6.6 \%\end{array}$ & $\begin{array}{l}0.1 \% \\
0.1 \%\end{array}$ & $\begin{array}{c}12.4 \% * \\
2.4 \%\end{array}$ & $\begin{array}{c}-0.5 \% \\
1.3 \%\end{array}$ & $\begin{array}{c}-34.9 \% \\
-6.6 \%\end{array}$ & $\begin{array}{c}-0.6 \% \\
1.2 \%\end{array}$ & $\begin{array}{c}-47.3 \%{ }^{*} \\
-9.0 \%{ }^{*}\end{array}$ \\
\hline+2 & $\begin{array}{l}\text { Mean } \\
\text { Median }\end{array}$ & 60 & $\begin{array}{l}-1.8 \% \\
-1.2 \%\end{array}$ & $\begin{array}{l}3.8 \% \\
0.0 \%\end{array}$ & 22 & $\begin{array}{l}-3.3 \% \\
-2.1 \%\end{array}$ & $\begin{array}{l}3.0 \% \\
-0.3 \%\end{array}$ & 17 & $\begin{array}{l}16.1 \% \\
-0.4 \%\end{array}$ & $\begin{array}{l}8.9 \% \\
0.3 \%\end{array}$ & $\begin{array}{l}1.5 \% \\
0.9 \%\end{array}$ & $\begin{array}{l}0.8 \% \\
0.3 \%\end{array}$ & $\begin{array}{c}-17.9 \% \\
-0.8 \%\end{array}$ & $\begin{array}{l}-5.1 \% \\
-0.3 \%\end{array}$ & $\begin{array}{l}-19.4 \% \\
-1.7 \%\end{array}$ & $\begin{array}{l}-6.0 \% \\
-0.6 \%\end{array}$ \\
\hline+3 & $\begin{array}{l}\text { Mean } \\
\text { Median }\end{array}$ & 49 & $\begin{array}{r}4.3 \% \\
-0.8 \%\end{array}$ & $\begin{array}{l}-1.9 \% \\
-4.3 \%\end{array}$ & 20 & $\begin{array}{l}-0.2 \% \\
-0.3 \%\end{array}$ & $\begin{array}{l}8.7 \% \\
0.1 \%\end{array}$ & 14 & $\begin{array}{l}0.4 \% \\
2.9 \%\end{array}$ & $\begin{array}{l}2.8 \% \\
-0.9 \%\end{array}$ & $\begin{array}{r}4.5 \% \\
-0.5 \%\end{array}$ & $\begin{array}{l}-10.6 \% \\
-4.4 \%{ }^{*}\end{array}$ & $\begin{array}{c}3.9 \% \\
-3.7 \% \text { ** }\end{array}$ & $\begin{array}{c}-4.7 \% \\
-3.4 \%^{* *}\end{array}$ & $\begin{array}{l}-0.5 \% \\
-3.2 \%\end{array}$ & $\begin{array}{l}5.9 \% \\
1.0 \%\end{array}$ \\
\hline+4 & $\begin{array}{l}\text { Mean } \\
\text { Median }\end{array}$ & 41 & $\begin{array}{l}-1.5 \% \\
0.1 \%\end{array}$ & $\begin{array}{l}-6.9 \% \\
-2.4 \%\end{array}$ & 15 & $\begin{array}{l}-4.0 \% \\
-2.6 \%\end{array}$ & $\begin{array}{l}10.7 \% \\
-5.4 \%\end{array}$ & 12 & $\begin{array}{l}-5.7 \% \\
-1.3 \%\end{array}$ & $\begin{array}{l}-6.8 \% \\
1.6 \%\end{array}$ & $\begin{array}{l}2.6 \% \\
2.7 \%\end{array}$ & $\begin{array}{c}-17.7 \% \\
3.0 \%\end{array}$ & $\begin{array}{l}4.2 \% \\
1.4 \%\end{array}$ & $\begin{array}{l}-0.1 \% \\
-4.0 \%{ }^{*}\end{array}$ & $\begin{array}{r}1.6 \% \\
-1.3 \%\end{array}$ & $\begin{array}{l}17.5 \% \\
-7.0 \%\end{array}$ \\
\hline+5 & $\begin{array}{l}\text { Mean } \\
\text { Median }\end{array}$ & 34 & $\begin{array}{l}-1.5 \% \\
-1.0 \%\end{array}$ & $\begin{array}{l}6.2 \% \\
0.5 \%\end{array}$ & 14 & $\begin{array}{l}-1.3 \% \\
-1.8 \%\end{array}$ & $\begin{array}{l}-3.1 \% \\
-8.6 \%\end{array}$ & 12 & $\begin{array}{l}-0.8 \% \\
0.1 \%\end{array}$ & $\begin{array}{l}17.6 \% \\
-1.7 \%\end{array}$ & $\begin{array}{l}-0.2 \% \\
0.8 \%\end{array}$ & $\begin{array}{l}9.3 \% \\
9.1 \%\end{array}$ & $\begin{array}{l}-0.7 \% \\
-1.1 \%\end{array}$ & $\begin{array}{c}-11.4 \% \\
2.2 \%\end{array}$ & $\begin{array}{l}-0.5 \% \\
-2.0 \%\end{array}$ & $\begin{array}{l}-20.7 \% \\
-6.9 \%^{*}\end{array}$ \\
\hline $\begin{array}{l}\text { IPO Year } \\
\text { Current UACC }\end{array}$ & $\begin{array}{l}\text { Mean } \\
\text { Median }\end{array}$ & 84 & $\begin{array}{l}2.2 \% \\
1.4 \%\end{array}$ & & 24 & $\begin{array}{l}3.7 \% \\
2.6 \%\end{array}$ & & 24 & $\begin{array}{c}12.3 \% \\
3.1 \%\end{array}$ & & $\begin{array}{l}-1.5 \% \\
-1.2 \%\end{array}$ & & $\begin{array}{l}-10.2 \% \\
-1.7 \% \text { ** }\end{array}$ & & $\begin{array}{l}-8.6 \% \\
-0.5 \%\end{array}$ & \\
\hline
\end{tabular}

$* * *$ significance at the 0.01 level, ** significance at the 0.05 level, * significance at the 0.10 level. 
Table 5 (continued)

Magnitude of Abnormal Accruals and Growth in Net Operating Assets

Panel B: Multivariate Analysis

\begin{tabular}{|c|c|c|c|c|c|c|c|c|c|c|c|c|c|c|c|c|c|}
\hline \multirow[b]{3}{*}{ Independent Variable } & \multirow[b]{3}{*}{$\begin{array}{l}\text { Predicted } \\
\text { Sign }\end{array}$} & \multicolumn{8}{|c|}{5 Years Pre-IPO } & \multicolumn{8}{|c|}{5 Years Post-IPO } \\
\hline & & \multicolumn{4}{|c|}{ UTACC } & \multicolumn{4}{|c|}{ GNOA } & \multicolumn{4}{|c|}{ UTACC } & \multicolumn{4}{|c|}{ GNOA } \\
\hline & & $\begin{array}{c}\text { Coef. } \\
(1)\end{array}$ & $\begin{array}{c}\text { t-stat } \\
(1)\end{array}$ & $\begin{array}{c}\text { Coef. } \\
(2)\end{array}$ & $\begin{array}{c}\text { t-stat } \\
(2)\end{array}$ & $\begin{array}{c}\text { Coef. } \\
(3)\end{array}$ & $\begin{array}{c}\text { t-stat } \\
(3)\end{array}$ & $\begin{array}{c}\text { Coef. } \\
(4)\end{array}$ & $\begin{array}{c}\text { t-stat } \\
(4)\end{array}$ & $\begin{array}{c}\text { Coef. } \\
(5)\end{array}$ & $\begin{array}{c}\text { t-stat } \\
(5)\end{array}$ & $\begin{array}{c}\text { Coef. } \\
(6)\end{array}$ & $\begin{array}{c}\text { t-stat } \\
(6)\end{array}$ & $\begin{array}{l}\text { Coef. } \\
(7)\end{array}$ & $\begin{array}{c}\text { t-stat } \\
(7)\end{array}$ & $\begin{array}{c}\text { Coef. } \\
(8)\end{array}$ & $\begin{array}{c}\text { t-stat } \\
(8)\end{array}$ \\
\hline Intercept & $?$ & 0.031 & 1.37 & -0.124 & $-2.74^{* * *}$ & 0.197 & $2.59^{* * *}$ & -0.247 & $-1.66^{*}$ & 0.134 & 1.33 & 0.167 & 1.09 & 0.964 & $6.91^{\star \star \star}$ & -0.492 & $-2.28^{* *}$ \\
\hline $\mathrm{PE}$ & - & -0.081 & $-3.41^{* * *}$ & -0.022 & $-2.35^{\star \star}$ & -0.305 & $-3.81^{* * *}$ & -0.022 & -0.74 & -0.156 & -1.51 & -0.071 & $-2.47^{* *}$ & -1.029 & $-6.16^{\star * *}$ & -0.122 & $-2.99^{* \star *}$ \\
\hline LAMBDA & & 0.030 & $1.74^{*}$ & & & 0.154 & $2.72^{\star \star * *}$ & & & 0.052 & 0.73 & & & 0.587 & $5.81^{* * *}$ & & \\
\hline PE*LAMBDA & & 0.020 & 0.76 & & & 0.024 & 0.29 & & & -0.018 & -0.19 & & & -0.395 & $-2.82^{\star * *}$ & & \\
\hline Pseudo-R-square $^{\mathrm{d}}$ & & $67.92 \%$ & & & & $67.92 \%$ & & & & $49.69 \%$ & & & & $49.69 \%$ & & & \\
\hline $\ln$ (Total Assets) & & & & -0.014 & $-1.99^{* *}$ & & & 0.032 & 1.33 & & & 0.005 & 0.19 & & & 0.010 & 0.30 \\
\hline $\ln ($ Sales $)$ & & & & 0.020 & $2.56^{\star \star}$ & & & -0.008 & -0.30 & & & -0.017 & -0.64 & & & 0.014 & 0.38 \\
\hline Book Value / Total Assets & & & & 0.070 & $2^{* *}$ & & & 0.083 & 0.72 & & & -0.034 & -0.31 & & & 0.374 & $2.42^{* *}$ \\
\hline Sales Growth & & & & -0.062 & $-2.97^{\star * *}$ & & & 0.183 & $2.72^{\star \star \star}$ & & & -0.040 & -0.54 & & & 0.074 & 0.70 \\
\hline Leverage & & & & 0.023 & 0.66 & & & 0.001 & 0.01 & & & 0.000 & 0.00 & & & 0.193 & 1.26 \\
\hline RNOA & & & & 0.036 & $4.7^{\star \star \star}$ & & & -0.009 & -0.38 & & & 0.137 & 1.60 & & & 0.784 & $6.4^{* * *}$ \\
\hline Q-Ratio & & & & 0.016 & $1.96^{*}$ & & & 0.065 & $2.45^{\star *}$ & & & 0.024 & 0.85 & & & 0.042 & 1.04 \\
\hline Oper_Cycle & & & & 0.000 & 1.59 & & & 0.000 & 0.67 & & & 0.000 & 0.52 & & & 0.000 & $2.11^{* *}$ \\
\hline Age & & & & 0.000 & 0.37 & & & -0.001 & -0.94 & & & 0.000 & -0.05 & & & -0.001 & -0.92 \\
\hline Cash / Total Assets & & & & -0.104 & -1.43 & & & -0.238 & -1.00 & & & -0.198 & -1.05 & & & 0.501 & $1.85^{\star}$ \\
\hline CAPEX / Total Assets & & & & -0.079 & -0.79 & & & 0.813 & $-2.48^{\star \star}$ & & & 0.015 & 0.06 & & & 0.459 & 1.20 \\
\hline D_loss & & & & -0.032 & $-4.44^{\star \star \star}$ & & & -0.031 & -1.33 & & & -0.055 & $-1.79^{*}$ & & & 0.087 & $1.97^{* *}$ \\
\hline D_Audit_Quality & & & & 0.057 & $2.69^{\star * *}$ & & & -0.011 & -0.15 & & & -0.031 & -0.40 & & & 0.047 & 0.42 \\
\hline Adj-R-square & & $5.69 \%$ & & $26.25 \%$ & & $6.20 \%$ & & $13.37 \%$ & & $1.70 \%$ & & $3.92 \%$ & & $14.79 \%$ & & $27.87 \%$ & \\
\hline No. of Observations & & 297 & & 297 & & 304 & & 304 & & 319 & & 319 & & 324 & & 324 & \\
\hline
\end{tabular}

*** significance at the 0.01 level, ** significance at the 0.05 level, * significance at the 0.10 level.

The distribution of each variable is truncated at the extreme $\pm 1 \%$ values.

${ }^{a}$ Differences in means are tested for significance using a two-tailed t-test; differences in medians are tested for significance using a two-tailed Wilcoxon signed rank test.

${ }^{b}$ The average of five years' annual UTACC and GNOA variables. For firms that do not survive for five full years after the IPO, the maximum number of years for which COMPUSTAT data is available is used.

c Current unexpected discretionary accruals are derived from the cross-sectional modified Jones model used by Teoh et al. (1998a, 1998b). (See section III.)

${ }^{\mathrm{d}}$ MacKelvey-Zavonia Pseudo-R-square for the first stage PROBIT model in the Heckman (1979) procedure.

Note: Panel A's summary of five years' pre-IPO and five years' post-IPO excludes firm-year observations during restructuring periods. 


\section{Table 5 (continued) \\ Magnitude of Abnormal Accruals and Growth in Net Operating Assets}

Legend:

UTACC Unexpected discretionary total accruals are derived from the cross-sectional modified Jones model (see section III). To control for the asymmetric recognition of gains and losses, I augmented the modified Jones model with the following independent variables: cash flow from operations in year $\mathrm{t}\left(\mathrm{CF}_{\mathrm{t}}\right)$, a dummy variable set to 1 if $\mathrm{CF}_{\mathrm{t}}<1$ and 0 otherwise $\left(\mathrm{DCF}_{\mathrm{t}}\right)$, and an interactive variable, $\mathrm{CF}_{\mathrm{t}} \mathrm{x} \mathrm{DCF}_{\mathrm{t}}(\mathrm{Ball}$ and Shivakumar (2006a).

GNOA Industry adjusted growth in net operating assets after subtracting the industry median (same 4-digit SIC codes) GNOA for the same year: $\mathrm{GNOA}_{\mathrm{j}, \mathrm{t}}=\left(\mathrm{NOA}_{\mathrm{j}, \mathrm{t}}-\mathrm{NOA}_{\mathrm{j}, \mathrm{t}-1}\right) / \mathrm{INOA}_{\mathrm{j}, \mathrm{t}-1}$ l, where: NOA: common equity: [common equity (\#60) + preferred treasury stock (\#227) - preferred dividends in arrears (\#242)] + financial obligations: [debt in current liabilities (\#34) + total long-term debt (\#9) + preferred stock (\#130) preferred treasury stock (\#227) + preferred dividends in arrears (\#242)] - financial assets: [cash and short-term Investments (\#1) + investments and advances minus other (\#32)] + minority interest (\#38) (Nissim and Penman 2003).

PE Dummy variable set to 1 for PE-backed firms (both majority- and minority-owned) and 0 for firms owned by management.

LAMBDA: $\quad$ Following the Heckman (1979) procedure, in the first stage I estimate a PROBIT model with, as predictors, size (alternatively defined as the natural logarithms of total assets or sales), ratio of book value of equity to total assets, growth (in sales), leverage, profitability (operating income divided by net operating assets), quick ratio, length of the operating cycle, age, cash and capital expenditures (both divided by total assets), a dummy for loss firms, and audit quality (a dummy for the big national accounting firms). Estimates of the PROBIT model are used to compute an inverse Mills' ratio for each firm. In the second stage, the inverse Mills' ratio is added to equation (2) as a control variable. To allow its coefficient to vary between the two groups of firms, an interactive variable (PE*LAMBDA) is also included.

$\ln$ (Total Assets) The natural logarithm of total assets (\#6).

ln(Total Sales) The natural logarithm of total sales (\#12).

Book Value Book value of equity: total common equity (\#60) + carrying value of preferred stock (\#130) + deferred taxes and investment tax credit (\#35).

Sales Growth Growth in sales (\#12) from year $\mathrm{t}-1$ to year $\mathrm{t}$.

Leverage Total debt (\#9+\#34) divided by total assets at end of the year (\#6).

RNOA Operating Income (OpI) divided by net operating assets at end of year t-1 $\left(\mathrm{NOA}_{\mathrm{t}-1}\right)$, where: OpI: earnings: [net income (\#172) - preferred dividends (\#19) + change in marketable securities adjustment (change in \#238) + change in cumulative translation adjustment (change in $\# 230)]+$ net interest expense: [after-tax interest expense $(\# 15 \times(1$ - marginal tax rate $))+$ preferred dividends $(\# 19)-$ after-tax interest income $(\# 62 \times(1$ - marginal tax rate) $)+$ minority interest in income (\#49) minus the change in marketable securities adjustment (change in \#238)], where the marginal tax rate is the top statutory federal tax rate plus $2 \%$ average state tax rate. The top federal statutory corporate tax rate was $48 \%$ in $1971-1978,46 \%$ in $1979-1986,40 \%$ in $1987,34 \%$ in $1988-1992$, and $35 \%$ in 1993-2003 (Nissim and Penman 2003).

Q-Ratio

Oper_Cycle

Cash and short-term investment (\#1) plus total receivables (\#2) divided by current liabilities (\#5).

Operating cycle days (receivable collection period plus inventory turnover in days), calculated as: (yearly average accounts receivable \#2)/(total revenues/360 \#12) + (yearly average inventory \#3)/(cost of goods sold/360 \#41).

Age Number of years since incorporation (first appearance on COMPUSTAT).

Cash Cash and short-term investment (\#1) divided by total assets at end of year $\mathrm{t}(\# 6)$.

CAPEX Capital expenditures (\#128) divided by total assets at end of year $\mathrm{t}$ (\#6).

D_Loss Dummy variable set to 1 for firms with negative net income (\#172) during year $t$ and 0 otherwise.

D_Audit_Quality Dummy variable set to 1 for firms audited by one of the big national auditing firms (\#149). 
Table 6

Timely Loss Recognition by Firm Type

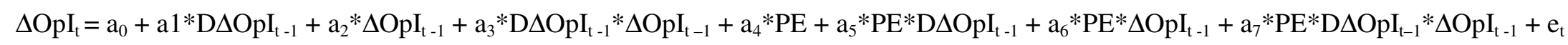

5 Years Pre-IPO

\begin{tabular}{|c|c|c|c|c|c|c|c|c|c|c|c|c|c|c|}
\hline \multirow[b]{2}{*}{ Independent Variable } & \multirow{2}{*}{\multicolumn{2}{|c|}{$\begin{array}{c}\text { Predicted } \\
\text { Sign } \\
\end{array}$}} & \multicolumn{6}{|c|}{5 Years Pre-IPO } & \multicolumn{6}{|c|}{5 Years Post-IPO } \\
\hline & & & $\begin{array}{l}\text { Coef. } \\
\text { (1) }\end{array}$ & $\begin{array}{l}\text { t-stat } \\
(1) \\
\end{array}$ & $\begin{array}{c}\text { Coef. } \\
(2)\end{array}$ & $\begin{array}{l}\text { t-stat } \\
(2) \\
\end{array}$ & $\begin{array}{c}\text { Coef. } \\
(3)\end{array}$ & $\begin{array}{c}\text { t-stat } \\
\text { (3) }\end{array}$ & $\begin{array}{c}\text { Coef. } \\
(4)\end{array}$ & $\begin{array}{l}\text { t-stat } \\
(4)\end{array}$ & $\begin{array}{c}\text { Coef. } \\
(5)\end{array}$ & $\begin{array}{c}\text { t-stat } \\
(5) \\
\end{array}$ & $\begin{array}{c}\text { Coef. } \\
(6)\end{array}$ & $\begin{array}{c}\text { t-stat } \\
(6) \\
\end{array}$ \\
\hline Intercept & $\left(a_{0}\right)$ & $?$ & 0.015 & 0.69 & 0.061 & 1.39 & -0.182 & $-2.57^{* *}$ & 0.018 & 0.66 & 0.046 & 0.52 & -0.035 & -0.38 \\
\hline $\mathrm{D} \Delta \mathrm{OpI}_{\mathrm{t}-1}$ & $\left(a_{1}\right)$ & $?$ & 0.010 & 0.28 & -0.006 & -0.19 & 0.004 & 0.15 & 0.009 & 0.19 & 0.017 & 0.37 & 0.028 & 0.76 \\
\hline$\Delta \mathrm{OpI}_{\mathrm{t}-1}$ & $\left(\mathrm{a}_{2}\right)$ & $?$ & -0.445 & $-1.7^{*}$ & -0.844 & $-3.06^{\star \star *}$ & -1.052 & $-5.3^{\star \star \star}$ & -0.093 & -0.50 & -0.151 & -0.77 & -0.084 & -0.55 \\
\hline $\mathrm{D} \Delta \mathrm{OpI}_{\mathrm{t}-1} * \Delta \mathrm{OpI}_{\mathrm{t}-1}$ & $\left(a_{3}\right)$ & $?$ & 0.396 & 1.06 & 0.764 & $2.2^{* *}$ & 0.752 & $2.93^{* *}$ & 0.342 & 1.04 & 0.560 & 1.29 & -0.533 & -1.38 \\
\hline $\mathrm{PE}$ & $\left(a_{4}\right)$ & $?$ & -0.028 & -1.05 & -0.043 & -0.93 & -0.041 & $-2.21^{* *}$ & -0.026 & -0.84 & -0.013 & -0.14 & 0.002 & 0.07 \\
\hline $\mathrm{PE} * \mathrm{D} \Delta \mathrm{OpI}_{\mathrm{t}-1}$ & $\left(a_{5}\right)$ & $?$ & -0.013 & -0.33 & -0.023 & -0.61 & 0.022 & 0.84 & -0.029 & -0.58 & -0.035 & -0.68 & -0.014 & -0.35 \\
\hline $\mathrm{PE}^{*} \Delta \mathrm{OpI}_{\mathrm{t}-1}$ & $\left(a_{6}\right)$ & + & 0.548 & $1.68^{*}$ & 0.741 & $2.3^{* *}$ & 1.185 & $5.12^{\star \star \star}$ & 0.064 & 0.30 & 0.088 & 0.39 & -0.069 & -0.40 \\
\hline $\mathrm{PE}^{2} * \Delta \mathrm{OpI}_{\mathrm{t}-1} * \Delta \mathrm{OpI}_{\mathrm{t}-1}$ & $\left(a_{7}\right)$ & - & -1.023 & $-2.37^{* *}$ & -1.182 & $-3.01^{* * *}$ & -1.343 & $-4.74^{\star \star *}$ & -1.017 & $-2.71^{* * *}$ & -1.128 & $-2.41^{* *}$ & -0.024 & -0.06 \\
\hline LAMBDA & & $?$ & & & 0.026 & 0.81 & & & & & 0.033 & 0.54 & & \\
\hline PE*LAMBDA & & $?$ & & & -0.043 & -0.99 & & & & & -0.177 & -1.29 & & \\
\hline Pseudo-R-square $^{a}$ & & & & & $59.51 \%$ & & & & & & $51.37 \%$ & & & \\
\hline $\ln$ (Total Assets) & & & & & & & -0.012 & -1.10 & & & & & -0.009 & -0.64 \\
\hline $\ln$ (Sales) & & & & & & & 0.023 & $1.99^{* *}$ & & & & & 0.005 & 0.35 \\
\hline Book Value / Total Assets & & & & & & & 0.113 & $2.13^{* *}$ & & & & & 0.035 & 0.49 \\
\hline Sales Growth & & & & & & & 0.058 & 1.65 & & & & & 0.037 & 0.96 \\
\hline Leverage & & & & & & & 0.102 & $1.93^{*}$ & & & & & 0.077 & 1.17 \\
\hline RNOA & & & & & & & 0.660 & $12.66^{\star * *}$ & & & & & 0.693 & $9.11^{* \star *}$ \\
\hline Q-Ratio & & & & & & & -0.010 & -0.84 & & & & & -0.009 & -0.55 \\
\hline Oper_Cycle & & & & & & & 0.000 & $1.72^{*}$ & & & & & 0.000 & -1.09 \\
\hline Age & & & & & & & -0.001 & $-2.46^{\star *}$ & & & & & 0.000 & 0.72 \\
\hline Cash / Total Assets & & & & & & & 0.020 & 0.18 & & & & & 0.003 & 0.02 \\
\hline CAPEX / Total Assets & & & & & & & -0.248 & -1.52 & & & & & -0.642 & $-3.76^{\star * *}$ \\
\hline D_loss & & & & & & & 0.005 & 0.47 & & & & & -0.035 & $-1.88^{*}$ \\
\hline D_Audit_Quality & & & & & & & 0.006 & 0.21 & & & & & -0.006 & -0.15 \\
\hline Adj-R-square & & & $11.06 \%$ & & $19.11 \%$ & & $63.08 \%$ & & $7.21 \%$ & & $9.88 \%$ & & $49.00 \%$ & \\
\hline No. of Observations & & & 258 & & 210 & & 210 & & 306 & & 246 & & 246 & \\
\hline
\end{tabular}

$* * *$ significance at the 0.01 level, $* *$ significance at the 0.05 level, $*$ significance at the 0.10 level.

Each variable in the table is truncated at the extreme $\pm 1 \%$ values of its distribution.

${ }^{a}$ MacKelvey-Zavonia Pseudo-R-square for the first stage PROBIT model in the Heckman (1979) procedure.

5 Years Post-IPO 


\section{Table 6 (continued) \\ Timely Loss Recognition by Firm Type}

\section{Legend:}

$\Delta \mathrm{OpI}_{\mathrm{t}}$ : $\quad$ Change in the earnings measure from year $\mathrm{t}-1$ to year $\mathrm{t}$, standardized by net operating assets at the end of year $\mathrm{t}-1$. Earnings are measured as operating income $(\mathrm{OpI})$, as defined below.

D $\Delta \mathrm{OpI}: \quad$ Dummy variable set to 1 if $\Delta \mathrm{OpI}_{\mathrm{t}-1}<0$ and 0 otherwise.

PE:

Dummy variable set to 1 for PE-backed firms (both majority- and minority-owned) and 0 for firms owned by management.

LAMBDA: $\quad$ Following the Heckman (1979) procedure, in the first stage I estimate a PROBIT model with, as predictors, size (alternatively defined as the natural logarithms of total assets or sales), ratio of book value of equity to total assets, growth (in sales), leverage, profitability (operating income divided by net operating assets), quick ratio, length of the operating cycle, age, cash and capital expenditures (both divided by total assets), a dummy for loss firms, and audit quality (a dummy for the big national accounting firms). Estimates of the PROBIT model are used to compute an inverse Mills' ratio for each firm. In the second stage, the inverse Mills' ratio is added to equation (3) as a control variable. To allow its coefficient to vary between the two groups of firms, an interactive variable (PE*LAMBDA) is also included.

OpI

Operating income divided by net operating assets (NOA) at end of year $\mathrm{t}-1$, where: NOA: common equity: [common equity (\#60) + preferred treasury stock (\#227) - preferred dividends in arrears (\#242)] + financial obligations: [debt in current liabilities (\#34) + total long-term debt (\#9) + preferred stock (\#130) - preferred treasury stock (\#227) + preferred dividends in arrears (\#242)] - financial assets: [cash and short-term investments (\#1) + investments and advances minus other (\#32)] + minority interest (\#38). Operating income: earnings: [net income (\#172) preferred dividends (\#19) + change in marketable securities adjustment (change in \#238) + change in cumulative translation adjustment (change in \#230)] + net interest expense: [after-tax interest expense $(\# 15 \times(1$ - marginal tax rate $))+$ preferred dividends $(\# 19)-$ after-tax interest income $(\# 62 \times(1$ - marginal tax rate $))+$ minority interest in income (\#49) minus the change in marketable securities adjustment (change in \#238)], where the marginal tax rate is the top statutory federal tax rate plus $2 \%$ average state tax rate. The top federal statutory corporate tax rate was $48 \%$ in $1971-1978,46 \%$ in $1979-1986,40 \%$ in $1987,34 \%$ in $1988-1992$, and 35\% in 1993-2005 (Nissim and Penman 2003).

All control variables are as defined in Table 5. 
Table 7

Accrual Model for Timely Loss Recognition by Firm Type

$\mathrm{ACC}_{\mathrm{t}}=\mathrm{b}_{0}+\mathrm{b}_{1} * \mathrm{DCFO}_{\mathrm{t}}+\mathrm{b}_{2} * \mathrm{CFO}_{\mathrm{t}}+\mathrm{b}_{3} * \mathrm{DCFO}_{\mathrm{t}} * \mathrm{CFO}+\mathrm{b}_{4} * \mathrm{PE}+\mathrm{b}_{5} * \mathrm{PE}^{*} \mathrm{DCFO}_{\mathrm{t}}+\mathrm{b}_{6} * \mathrm{PE}^{*} \mathrm{CFO}_{\mathrm{t}}+\mathrm{b}_{7} * \mathrm{PE}^{*} \mathrm{DCFO}_{\mathrm{t}} * \mathrm{CFO}_{\mathrm{t}}+\mathrm{e}_{\mathrm{t}}$

5 Years Pre-IPO

\begin{tabular}{|c|c|c|c|c|c|c|c|c|c|c|c|c|c|c|}
\hline \multirow[b]{2}{*}{ Independent Variable } & \multirow{2}{*}{\multicolumn{2}{|c|}{$\begin{array}{c}\text { Predicted } \\
\text { Sign } \\
\end{array}$}} & \multicolumn{6}{|c|}{5 Years Pre-IPO } & \multicolumn{6}{|c|}{5 Years Post-IPO } \\
\hline & & & $\begin{array}{c}\text { Coef. } \\
\text { (1) }\end{array}$ & $\begin{array}{c}\text { t-stat } \\
(1)\end{array}$ & $\begin{array}{c}\text { Coef. } \\
\text { (2) }\end{array}$ & $\begin{array}{c}\text { t-stat } \\
(2)\end{array}$ & $\begin{array}{c}\text { Coef. } \\
(3)\end{array}$ & $\begin{array}{c}\text { t-stat } \\
\text { (3) }\end{array}$ & $\begin{array}{c}\text { Coef. } \\
(4)\end{array}$ & $\begin{array}{c}\text { t-stat } \\
(4)\end{array}$ & $\begin{array}{c}\text { Coef. } \\
(5)\end{array}$ & $\begin{array}{c}\text { t-stat } \\
(5) \\
\end{array}$ & $\begin{array}{c}\text { Coef. } \\
(6)\end{array}$ & $\begin{array}{c}\text { t-stat } \\
(6) \\
\end{array}$ \\
\hline Intercep $_{t}$ & $\left(b_{0}\right)$ & $?$ & -0.038 & $-3.05^{\star \star \star}$ & -0.010 & -0.40 & -0.012 & -0.28 & -0.020 & -1.54 & -0.055 & $-1.73^{*}$ & -0.088 & $-2.35^{\star \star}$ \\
\hline $\mathrm{DCFO}_{\mathrm{t}}$ & $\left(b_{1}\right)$ & $?$ & 0.021 & 0.49 & 0.053 & 1.18 & 0.013 & 0.29 & 0.056 & 1.36 & 0.042 & 1.15 & 0.041 & 1.27 \\
\hline $\mathrm{CFO}_{\mathrm{t}}$ & $\left(b_{2}\right)$ & - & -0.284 & $-2.38^{* *}$ & -0.375 & $-2.51^{* *}$ & -0.615 & $-3.94^{\star \star *}$ & -0.406 & $-3.65^{\star \star \star}$ & -0.397 & $-3.29^{\star *}$ & -0.466 & $-4.39^{* * *}$ \\
\hline $\mathrm{DCFO}_{\mathrm{t}} * \mathrm{CFO}_{\mathrm{t}}$ & $\left(b_{3}\right)$ & $?$ & -2.037 & $-2.15^{\star \star}$ & -1.427 & -1.60 & -1.471 & $-1.65^{*}$ & 0.498 & 0.49 & 0.376 & 0.44 & 0.101 & 0.13 \\
\hline $\mathrm{PE}$ & $\left(b_{4}\right)$ & $?$ & 0.010 & 0.72 & -0.036 & -1.47 & -0.010 & -0.68 & 0.012 & 0.84 & 0.054 & $1.65^{*}$ & 0.012 & 0.89 \\
\hline $\mathrm{PE}^{*} \mathrm{DCFO}_{\mathrm{t}}$ & $\left(b_{5}\right)$ & $?$ & -0.014 & -0.30 & -0.035 & -0.74 & -0.006 & -0.13 & -0.084 & $-1.9^{*}$ & -0.043 & -1.04 & -0.039 & -1.06 \\
\hline $\mathrm{PE}^{*} \mathrm{CFO}_{\mathrm{t}}$ & $\left(b_{6}\right)$ & $?$ & -0.365 & $-2.77^{\star \star \star}$ & -0.170 & -1.05 & 0.070 & 0.42 & -0.118 & -0.95 & -0.077 & -0.58 & -0.050 & -0.42 \\
\hline $\mathrm{PE}^{*} \mathrm{DCFO}_{\mathrm{t}}{ }^{*} \mathrm{CFO}_{\mathrm{t}}$ & $\left(b_{7}\right)$ & + & 2.506 & $2.58^{\star *}$ & 1.593 & $1.68^{*}$ & 1.502 & 1.59 & -0.210 & -0.20 & -0.543 & -0.59 & -0.101 & -0.12 \\
\hline LAMBDA & & $?$ & & & 0.020 & 1.32 & & & & & -0.022 & -1.14 & & \\
\hline PE*LAMBDA & & $?$ & & & 0.022 & 1.08 & & & & & -0.011 & -0.40 & & \\
\hline Pseudo-R-square $^{a}$ & & & & & $57.65 \%$ & & & & & & $51.69 \%$ & & & \\
\hline $\ln$ (Total Assets) & & & & & & & -0.020 & $-3.12^{* * *}$ & & & & & -0.010 & $-1.79^{*}$ \\
\hline $\ln$ (Sales) & & & & & & & 0.018 & $2.64^{\star \star}$ & & & & & 0.013 & $1.97^{\star *}$ \\
\hline Book Value / Total Assets & & & & & & & 0.013 & 0.43 & & & & & 0.080 & $2.87^{\star * *}$ \\
\hline Sales' Growth & & & & & & & 0.001 & 0.05 & & & & & 0.030 & $1.99^{* *}$ \\
\hline Leverage & & & & & & & -0.041 & -1.38 & & & & & -0.006 & -0.23 \\
\hline Q-Ratio & & & & & & & 0.019 & $2.88^{\star \star \star}$ & & & & & 0.007 & $1.81^{*}$ \\
\hline Oper_Cycle & & & & & & & 0.000 & 0.87 & & & & & 0.000 & $3.57^{* \star *}$ \\
\hline Age & & & & & & & 0.000 & 0.90 & & & & & 0.000 & 0.02 \\
\hline Cash / Total Assets & & & & & & & -0.104 & -1.63 & & & & & -0.141 & $-2.43^{* *}$ \\
\hline CAPEX / Total Assets & & & & & & & 0.166 & $1.84^{*}$ & & & & & 0.047 & 0.61 \\
\hline D_Audit_Quality & & & & & & & 0.001 & 0.08 & & & & & 0.009 & 0.56 \\
\hline Adj-R-square & & & $36.33 \%$ & & $36.67 \%$ & & $42.07 \%$ & & $24.41 \%$ & & $31.62 \%$ & & $45.30 \%$ & \\
\hline No. of Observations & & & 371 & & 293 & & 293 & & 400 & & 295 & & 295 & \\
\hline
\end{tabular}

$* * *$ significance at the 0.01 level, $* *$ significance at the 0.05 level, * significance at the 0.10 level.

Each variable in the table is truncated at the extreme $\pm 1 \%$ values of its distribution.

${ }^{a}$ MacKelvey-Zavonia Pseudo-R-square for the first stage PROBIT model in the Heckman (1979) procedure. 


\section{Table 7 (continued) \\ Accrual Model for Timely Loss Recognition by Firm Type}

\section{Legend:}

ACC $_{\mathrm{t}}$ : $\quad$ Total accruals divided by total assets at end of year t-1. For year>=1988: total accruals [income before extraordinary items (SCF) (\#123) net cash flow from operating activities (\#308) + extraordinary items and discounted operations (SCF) (\#124)] divided by total assets at end of year $\mathrm{t}$-1 (lagged \#6). For year<1988: [change in current assets during period $\mathrm{t}(\# 4)$ - change in current liabilities during period $\mathrm{t}(\# 5)$ change in cash and cash equivalents during period $t(\# 1)+$ change in current maturities of long-term debt and other short-term debt included in current liabilities during period $\mathrm{t}(\# 34)$ - depreciation and amortization expense during period $\mathrm{t}(\# 125)]$.

In addition, I eliminated firm-year observations with the following "non-articulation" events:

firm-year observations in which a company is involved in a merger or acquisition (\#AFTNT35 code \#1); firm-year observations in which a company reports "discontinued operations" greater than $\$ 10,000$ (\#66); and firm-year observations in which a company reports a gain or loss on foreign currency translations greater than $\$ 10,000$ (\#150) (Hribar and Collins 2002).

$\mathrm{CFO}_{\mathrm{t}}$ :

Cash flow from operations divided by total assets at the end of year $\mathrm{t}-1$. For year>=1988: net cash flow from operating activities (\#308) divided by total assets at end of year $\mathrm{t}-1$ (lagged \#6).

For year <1988: [funds from operations (\#110) - change in current assets during period t (\#4) + change in cash and cash equivalent during period $\mathrm{t}(\# 1)+$ change in current liabilities during period $\mathrm{t}(\# 5)$ - change in current maturities of long-term debt and other short-term debt included in current liabilities during period t (\#34)]. All variables are divided by total assets at end of year t-1 (lagged \#6) (Xie 2001).

$\mathrm{DCFO}_{\mathrm{t}}$ : $\quad$ Dummy variable that is 1 if $C F O_{t}<0$ and 0 otherwise.

PE:

Dummy variable set to 1 for PE-backed firms (both majority- and minority-owned) and 0 for firms owned by management.

LAMBDA:

Following the Heckman (1979) procedure, in the first stage I estimate a PROBIT model with, as predictors, size (alternatively defined as the natural logarithms of total assets or sales), ratio of book value of equity to total assets, growth (in sales), leverage, profitability (operating income divided by net operating assets), quick ratio, length of the operating cycle, age, cash and capital expenditures (both divided by total assets), a dummy for loss firms, and audit quality (a dummy for the big national accounting firms). Estimates of the PROBIT model are used to compute an inverse Mills' ratio for each firm. In the second stage, the inverse Mills' ratio is added to equation (4) as a control variable. To allow its coefficient to vary between the two groups of firms, an interactive variable (PE*LAMBDA) is also included.

All control variables are as defined in Table 5. 
Table 8

Market-Adjusted Performance by Firm Type

Panel A: Market-Adjusted Performance

\begin{tabular}{|c|c|c|c|c|c|c|c|}
\hline & & \multirow{2}{*}{$\begin{array}{c}\text { PE } \\
\text { Majority } \\
(1)\end{array}$} & \multirow{2}{*}{$\begin{array}{c}\text { PE } \\
\text { Minority } \\
(2)\end{array}$} & \multirow{2}{*}{$\begin{array}{c}\text { Mgmt } \\
\text { (3) }\end{array}$} & \multirow{2}{*}{$\frac{\text { Diff. }^{a}}{(1)-(2)}$} & \multirow{2}{*}{$\frac{\text { Diff. }}{(1)-(3)}$} & \multirow{2}{*}{$\frac{\text { Diff. }}{(2)-(3)}$} \\
\hline & & & & & & & \\
\hline No. of Firms & & 92 & 26 & 21 & & & \\
\hline \multicolumn{8}{|c|}{ Size and Book-to-Market (5x5) Adj. Returns ${ }^{b}$} \\
\hline 1 Year & $\begin{array}{l}\text { Mean } \\
\text { t-stat } \\
\text { Median }\end{array}$ & $\begin{array}{l}19.1 \% \\
8.8 \%\end{array}$ & $\begin{array}{l}-9.3 \% \\
-18.3 \%\end{array}$ & $\begin{array}{c}3.9 \% \\
-12.6 \%\end{array}$ & $\begin{array}{c}28.5 \% \\
(2.66) \\
27.1 \% \text { *** }\end{array}$ & $\begin{array}{c}15.3 \% \\
(1.81) \\
21.4 \%\end{array}$ & $\begin{array}{c}-13.2 \% \\
(-0.97) \\
-5.7 \%\end{array}$ \\
\hline 3 Year & $\begin{array}{l}\text { Mean } \\
\text { t-stat } \\
\text { Median }\end{array}$ & $\begin{array}{l}19.0 \% \\
9.7 \%\end{array}$ & $\begin{array}{l}-27.5 \% \\
-36.7 \%\end{array}$ & $\begin{array}{l}-4.9 \% \\
-16.8 \%\end{array}$ & $\begin{array}{c}46.5 \% \\
(2.59) \\
46.3 \% \text { ** }\end{array}$ & $\begin{array}{c}23.9 \% \\
(1.15) \\
26.5 \%{ }^{*}\end{array}$ & $\begin{array}{c}-22.6 \% \\
(-0.86) \\
-19.9 \%\end{array}$ \\
\hline 5 Year & $\begin{array}{l}\text { Mean } \\
\text { t-stat } \\
\text { Median }\end{array}$ & $\begin{array}{l}17.3 \% \\
-0.4 \%\end{array}$ & $\begin{array}{l}-56.8 \% \\
-66.3 \%\end{array}$ & $\begin{array}{l}-3.5 \% \\
-12.9 \%\end{array}$ & $\begin{array}{c}74.1 \% \\
(2.67) \\
65.9 \%{ }^{*}\end{array}$ & $\begin{array}{c}20.8 \% \\
(0.58) \\
12.5 \%\end{array}$ & $\begin{array}{l}-53.4 \\
(-1.66) \\
-53.4^{*}\end{array}$ \\
\hline \multicolumn{8}{|l|}{ Industry Adj. ROA } \\
\hline 1 Year & $\begin{array}{l}\text { Mean } \\
\text { Median }\end{array}$ & $\begin{array}{l}0.7 \% \\
0.5 \%\end{array}$ & $\begin{array}{l}0.5 \% \\
0.7 \%\end{array}$ & $\begin{array}{l}1.7 \% \\
1.9 \%\end{array}$ & $\begin{array}{l}0.2 \% \\
-0.3 \%\end{array}$ & $\begin{array}{l}-1.0 \% \\
-1.4 \%\end{array}$ & $\begin{array}{l}-1.2 \% \\
-1.2 \%\end{array}$ \\
\hline 3 Year & $\begin{array}{l}\text { Mean } \\
\text { Median }\end{array}$ & $\begin{array}{l}-0.2 \% \\
-0.2 \%\end{array}$ & $\begin{array}{l}-1.1 \% \\
-0.1 \%\end{array}$ & $\begin{array}{l}-0.1 \% \\
-0.7 \%\end{array}$ & $\begin{array}{r}1.0 \% \\
-0.1 \%\end{array}$ & $\begin{array}{l}-0.1 \% \\
0.4 \%\end{array}$ & $\begin{array}{l}-1.1 \% \\
0.5 \%\end{array}$ \\
\hline 5 Year & $\begin{array}{l}\text { Mean } \\
\text { Median }\end{array}$ & $\begin{array}{l}-0.2 \% \\
-0.2 \%\end{array}$ & $\begin{array}{l}-1.1 \% \\
-0.6 \%\end{array}$ & $\begin{array}{l}0.4 \% \\
0.0 \%\end{array}$ & $\begin{array}{l}1.0 \% \\
0.5 \%\end{array}$ & $\begin{array}{l}-0.6 \% \\
-0.1 \%\end{array}$ & $\begin{array}{l}-1.5 \% \\
-0.6 \%\end{array}$ \\
\hline \multicolumn{8}{|l|}{ Market-to-Book } \\
\hline 1 Year & $\begin{array}{l}\text { Mean } \\
\text { Median }\end{array}$ & $\begin{array}{l}3.28 \\
2.14\end{array}$ & $\begin{array}{l}2.26 \\
2.05\end{array}$ & $\begin{array}{l}3.19 \\
2.20\end{array}$ & $\begin{array}{c}1.01 \\
0.09^{\star * *}\end{array}$ & $\begin{array}{c}0.09 \\
-0.06^{* * *}\end{array}$ & $\begin{array}{l}-0.92 \\
-0.15\end{array}$ \\
\hline 3 Year & $\begin{array}{l}\text { Mean } \\
\text { Median }\end{array}$ & $\begin{array}{l}2.31 \\
2.08\end{array}$ & $\begin{array}{l}1.75 \\
1.49\end{array}$ & $\begin{array}{l}3.03 \\
2.93\end{array}$ & $\begin{array}{c}0.57 \\
0.59^{\star \star \star}\end{array}$ & $\begin{array}{c}-0.72 \\
-0.85^{\star \star \star}\end{array}$ & $\begin{array}{l}-1.29^{\star} \\
-1.44\end{array}$ \\
\hline 5 Year & $\begin{array}{l}\text { Mean } \\
\text { Median }\end{array}$ & $\begin{array}{l}2.77 \\
2.36\end{array}$ & $\begin{array}{l}2.01 \\
1.86\end{array}$ & $\begin{array}{l}2.84 \\
1.62\end{array}$ & $\begin{array}{c}0.76 \\
0.50^{\star * \star}\end{array}$ & $\begin{array}{c}-0.07 \\
0.74^{\star * *}\end{array}$ & $\begin{array}{l}-0.83 \\
0.24\end{array}$ \\
\hline \multicolumn{8}{|l|}{ Delisting } \\
\hline 1 Year & Mean & $0.0 \%$ & $0.0 \%$ & $0.0 \%$ & $0.0 \%$ & $0.0 \%$ & $0.0 \%$ \\
\hline 3 Year & Mean & $0.0 \%$ & $7.7 \%$ & $0.0 \%$ & $-7.7 \%$ & $0.0 \%$ & $7.7 \%$ \\
\hline 5 Year & Mean & $5.4 \%$ & $11.5 \%$ & $4.8 \%$ & $-6.1 \%$ & $0.7 \%$ & $6.8 \%$ \\
\hline Pre-IPO UTACC & $\begin{array}{l}\text { Mean } \\
\text { Median }\end{array}$ & $\begin{array}{l}-4.0 \% \\
-3.5 \%\end{array}$ & $\begin{array}{l}-4.7 \% \\
-3.7 \%\end{array}$ & $\begin{array}{l}0.4 \% \\
0.7 \%\end{array}$ & $\begin{array}{c}0.7 \% \\
0.2 \%{ }^{\star \star \star}\end{array}$ & $\begin{array}{l}-4.4 \%^{* * *} \\
-4.2 \%^{* * *}\end{array}$ & $\begin{array}{l}-5.1 \%^{* * *} \\
-4.3 \%^{* * *}\end{array}$ \\
\hline Underwriter Reputation & $\begin{array}{l}\text { Mean } \\
\text { Median }\end{array}$ & $\begin{array}{l}8.82 \\
9.10\end{array}$ & $\begin{array}{l}8.78 \\
9.10\end{array}$ & $\begin{array}{l}8.32 \\
8.83\end{array}$ & $\begin{array}{l}0.04 \\
0.00\end{array}$ & $\begin{array}{c}0.50 \\
0.27^{\star \star *}\end{array}$ & $\begin{array}{l}0.46 \\
0.27\end{array}$ \\
\hline Large PE Sponsors & Mean & $32.6 \%$ & $3.8 \%$ & & $28.8 \%$ *** & & \\
\hline
\end{tabular}

$* * *$ significance at the 0.01 level, $* *$ significance at the 0.05 level, $*$ significance at the 0.10 level.

The distribution of each variable is winsorized at the extreme $\pm 1 \%$ values.

${ }^{a}$ Differences in means are tested for significance using a two-tailed t-test; differences in medians are tested for significance using a two-tailed Wilcoxon signed rank test.

${ }^{\mathrm{b}}$ Due to the cross-correlation problem, the t-statistics for abnormal returns should not be translated into $p$-values; these $\mathrm{t}$-statistics appear in parentheses. 


\section{Table 8 (continued) Market-Adjusted Performance by Firm Type}

\section{Legend:}

Size and Book-to-Market (5x5) Adj. Returns: For each IPO, the adjusted market returns are calculated as the buyand-hold daily returns on the periods of 1 year, 3 years, and 5 years after the IPO, less the buy-and-hold returns on a Fama and French size and book-to-market (5x5) matched portfolio of daily value-weighted market returns index over the same period. The size and book-to-market portfolio returns are obtained from Kenneth French's Web site; http://mba.tuck.dartmouth.edu/pages/faculty/ken.french/data_library.html. If the sample firm delists during the relevant period, I add the delist return to the firm's buy-and-hold return and set the market-adjusted return equal to zero after the delisting date. When the delisting return is missing, I allocate it, following Shumway and Warther (1999) and the CRSP "white paper" on delisting returns (2001), according to the delisting code and exchange code.

Industry Adj. ROA: The average of 1 year, 3 years, or 5 years after the IPO matched-adjusted return on assets, which is defined as net income (\#172) plus net of tax interest expense (\#15) divided by total assets at end of year $\mathrm{t}-1$ (lagged \#6), minus the industry median ROA for the same period (based on 4-digit SIC codes). For firms that do not survive for the full 1 year, 3 years, or 5 years after the IPO, the maximum number of years for which COMPUSTAT data is available is used.

Market-to-Book: The market-to-book ratio is measured at the end of 1 year, 3 years, or 5 years since the IPO. For firms that do not survive the full 1 year, 3 years, or 5 years after the IPO, the maximum number of years for which COMPUSTAT data is available is used. Market value of equity is defined as common shares outstanding (\#25) multiplied by fiscal year closing price (\#199). Book value of equity is defined as total common equity (\#60) + carrying value of preferred stock (\#130) + deferred taxes and investment tax credit (\#35).

Delisting: The percentage of firms delisted from the NYSE, Amex, or Nasdaq due to bankruptcy, default, or liquidation (CRSP delisting codes 400 and above).

Pre-IPO UTACC: The average of 5 years' pre-IPO annual UTACC. Unexpected discretionary total accruals are derived from the cross-sectional modified Jones model (see section III). To control for the asymmetric recognition of gains and losses, I augmented the modified Jones model with the following independent variables: cash flow from operations in year $\mathrm{t}(\mathrm{CFt})$, a dummy variable set to 1 if $\mathrm{CFt}<1$ and o otherwise (DCFt), and an interactive variable, CFt x DCFt (Ball and Shivakumar 2006a).

Underwriter Reputation: The lead underwriter reputation rankings as measured by Carter et al. (1998) and updated on Jay's Ritter Web site: http://bear.cba.ufl.edu/ritter/rank.xls.

PE Sponsor Size: PE sponsors are ranked according to total investment (in \$US) during the years 1980-2005. Large PE sponsors include: Warburg Pincus, Carlyle Group, KKR, Apax, Blackstone, Goldman Sachs, J.P. Morgan, Welsh Carson Anderson \& Stone, Hicks Muse Tate \& Furst, 3i Group, Bain Capital, Thomas H. Lee, Morgan Stanley, and Cinven (Tiers 1-3 from Table 2). Small PE sponsors include all other PE sponsors. (Source: Thomson Financials, VentureXpert.) 


\section{Table 8 (continued) \\ Market-Adjusted Performance by Firm Type}

\section{Panel B: Fama-French Three Factors Calendar Time Portfolio Regressions}

\begin{tabular}{|c|c|c|c|c|c|c|}
\hline \multirow[b]{2}{*}{ Independent Variable } & \multicolumn{2}{|c|}{1 Year Ret } & \multicolumn{2}{|c|}{3 Years Ret } & \multicolumn{2}{|c|}{5 Years Ret } \\
\hline & $\begin{array}{l}\text { Coef. } \\
(1)\end{array}$ & $\begin{array}{c}\text { t-stat } \\
(1) \\
\end{array}$ & $\begin{array}{l}\text { Coef. } \\
(2)\end{array}$ & $\begin{array}{c}\text { t-stat } \\
(2) \\
\end{array}$ & $\begin{array}{l}\text { Coef. } \\
\text { (3) }\end{array}$ & $\begin{array}{c}\text { t-stat } \\
(3) \\
\end{array}$ \\
\hline \multicolumn{7}{|l|}{ PE Majority } \\
\hline Intercept & 0.004 & 0.82 & 0.003 & 0.99 & 0.001 & 0.39 \\
\hline RMF & 1.211 & $7.77^{* * *}$ & 0.953 & $9.41^{\star * \star}$ & 0.911 & $10.28^{* * \star}$ \\
\hline SMB & 0.915 & $4.72^{* \star \star}$ & 0.742 & $5.92^{* \star *}$ & 0.753 & $6.87^{* * *}$ \\
\hline HML & 0.328 & 1.43 & 0.336 & $2.28^{\star \star}$ & 0.386 & $2.99^{\star \star \star}$ \\
\hline Adj-R-square & $31.90 \%$ & & $38.78 \%$ & & $43.55 \%$ & \\
\hline No. of Observations & 197 & & 219 & & 219 & \\
\hline \multicolumn{7}{|l|}{ PE Minority } \\
\hline Intercept & -0.014 & -1.36 & -0.006 & -1.13 & -0.004 & -0.87 \\
\hline RMF & 1.527 & $4.99^{\star \star \star}$ & 1.128 & $7.05^{\star \star \star}$ & 1.162 & $8.7^{\star \star \star}$ \\
\hline SMB & 0.985 & $2.41^{* \star}$ & 1.070 & $5.33^{\star \star \star}$ & 1.026 & $6.13^{\star \star \star}$ \\
\hline HML & 0.507 & 1.11 & 0.255 & 1.08 & 0.352 & $1.78^{*}$ \\
\hline Adj-R-square & $18.83 \%$ & & $28.99 \%$ & & $36.63 \%$ & \\
\hline No. of Observations & 149 & & 232 & & 232 & \\
\hline \multicolumn{7}{|l|}{ Mgmt } \\
\hline Intercept & -0.009 & -0.95 & -0.001 & -0.08 & -0.009 & -1.51 \\
\hline RMF & 1.382 & $4.65^{\star \star *}$ & 1.148 & $5.56^{* * *}$ & 1.289 & $7.61^{* \star *}$ \\
\hline SMB & 0.512 & 1.57 & 0.889 & $3.82^{\star * *}$ & 0.629 & $3.05^{\star \star \star}$ \\
\hline HML & 0.793 & $1.91^{*}$ & 0.281 & 1.01 & 0.460 & $1.89^{*}$ \\
\hline Adj-R-square & $14.58 \%$ & & $22.51 \%$ & & $25.12 \%$ & \\
\hline No. of Observations & 121 & & 174 & & 213 & \\
\hline
\end{tabular}

$* * *$ significance at the 0.01 level, $* *$ significance at the 0.05 level, $*$ significance at the 0.10 level.

The distribution of each variable is truncated at the extreme $\pm 1 \%$ values.

Regression coefficients estimated in calendar time from the Fama-French (1993) three factor regression model:

$\mathrm{R}_{\mathrm{pt}}-\mathrm{R}_{\mathrm{ft}}=\mathrm{a}_{\mathrm{p}}+\mathrm{b}_{\mathrm{p}}\left(\mathrm{R}_{\mathrm{mt}}-\mathrm{R}_{\mathrm{ft}}\right)+\mathrm{s}_{\mathrm{p}} \mathrm{SMB}_{\mathrm{t}}+\mathrm{h}_{\mathrm{p}} \mathrm{HML}_{\mathrm{t}}+\varepsilon_{\mathrm{t}}$

where $R_{p t}$ is the equally weighted portfolio returns in calendar month $t$; $R_{f t}$ is the 30-day T-bill yield in month $t$; $R_{m t}$ is the return on the value weighted CRSP index; $\mathrm{SMB}_{\mathrm{t}}$ is the return on small firms minus the return on large firms; and $\mathrm{HML}_{\mathrm{t}}$ is the return on high book-to-market stocks minus the return on low book-to-market stocks in month $\mathrm{t}$. 
Table 9

\section{Market-Adjusted Performance by PE Sponsor Size}

\section{Panel A: Market-Adjusted Performance}

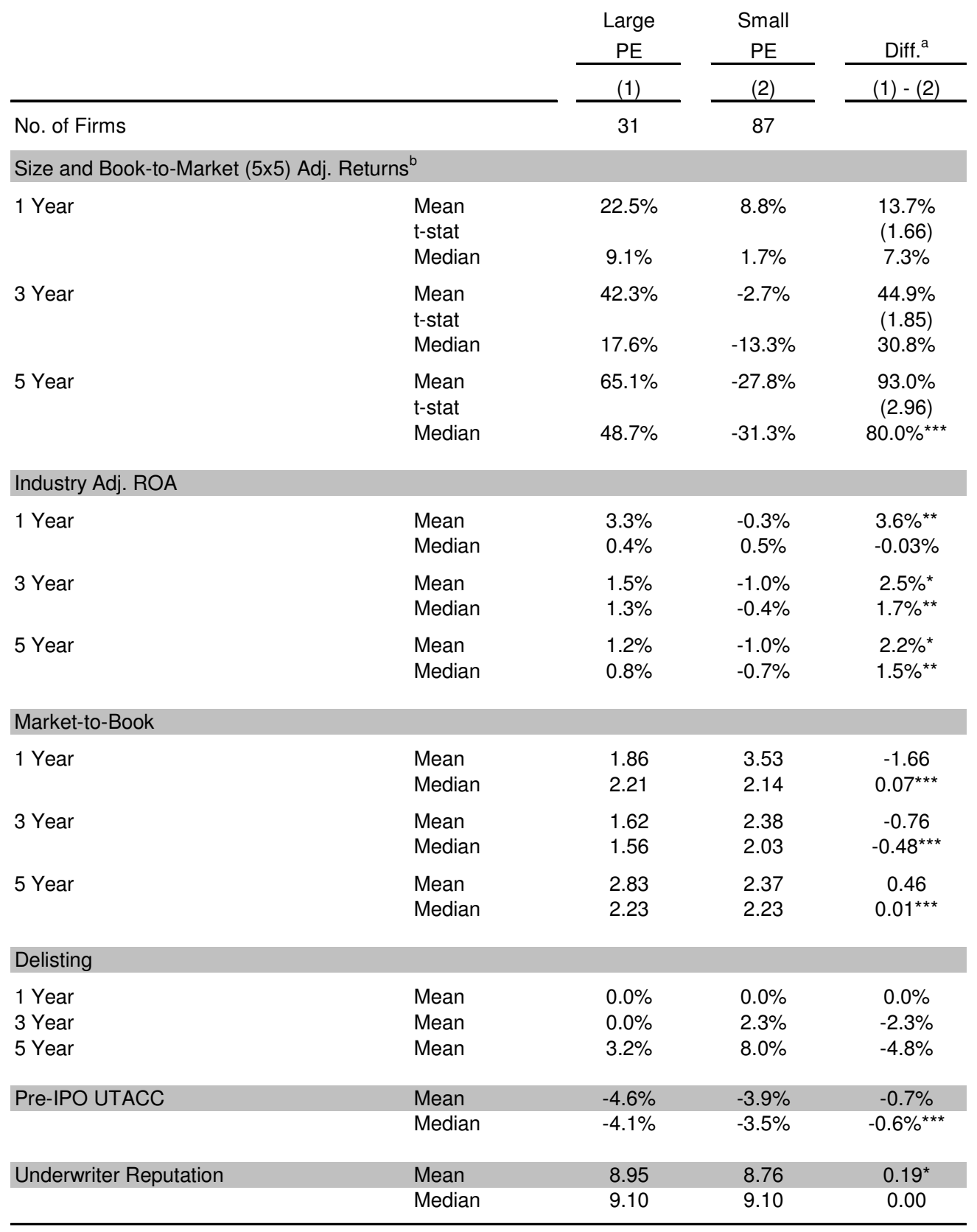

$* * *$ significance at the 0.01 level, ** significance at the 0.05 level, * significance at the 0.10 level.

The distribution of each variable is winsorized at the extreme $\pm 1 \%$ values.

${ }^{a}$ Differences in means are tested for significance using a two-tailed t-test; differences in medians are tested for significance using a two-tailed Wilcoxon signed rank test.

${ }^{\mathrm{b}}$ Due to the cross-correlation problem, the t-statistics for abnormal returns should not be translated into $p$-values; these t-statistics appear in parentheses.

All variables are as defined in Table 8 Panel A. 


\section{Table 9 (continued) \\ Market-Adjusted Performance by PE Sponsor Size}

Panel B: Fama-French Three Factors Calendar Time Portfolio Regressions

\begin{tabular}{|c|c|c|c|c|c|c|}
\hline \multirow[b]{2}{*}{ Independent Variable } & \multicolumn{2}{|c|}{1 Year Ret } & \multicolumn{2}{|c|}{3 Years Ret } & \multicolumn{2}{|c|}{5 Years Ret } \\
\hline & $\begin{array}{l}\text { Coef. } \\
(1)\end{array}$ & $\begin{array}{c}\text { t-stat } \\
(1) \\
\end{array}$ & $\begin{array}{l}\text { Coef. } \\
(2)\end{array}$ & $\begin{array}{c}\text { t-stat } \\
(2)\end{array}$ & $\begin{array}{l}\text { Coef. } \\
(3)\end{array}$ & $\begin{array}{c}\text { t-stat } \\
(3) \\
\end{array}$ \\
\hline \multicolumn{7}{|l|}{ Large PE } \\
\hline Intercept & 0.012 & $2.59^{\star \star}$ & 0.002 & 0.70 & 0.001 & 0.27 \\
\hline RMF & 1.235 & $8.79^{* * *}$ & 1.034 & $9.63^{\star * *}$ & 0.973 & $10.73^{\star * *}$ \\
\hline SMB & 0.965 & $5.56^{\star * *}$ & 0.832 & $6.39^{\star * *}$ & 0.810 & $7.36^{\star * *}$ \\
\hline HML & 0.349 & $1.71^{*}$ & 0.262 & $1.69^{*}$ & 0.339 & $2.58^{* *}$ \\
\hline Adj-R-square & $44.12 \%$ & & $39.26 \%$ & & $44.38 \%$ & \\
\hline No. of Observations & 165 & & 252 & & 252 & \\
\hline \multicolumn{7}{|l|}{ Small PE } \\
\hline Intercept & -0.018 & $-2.06^{\star *}$ & -0.009 & -1.55 & -0.007 & -1.34 \\
\hline RMF & 1.332 & $5.12^{\star \star \star}$ & 1.020 & $6.37^{\star \star \star}$ & 1.107 & $8.07^{* \star *}$ \\
\hline SMB & 1.047 & $3.08^{* * *}$ & 0.999 & $4.9^{\star \star \star}$ & 1.002 & $5.73^{\star \star \star}$ \\
\hline HML & 0.497 & 1.29 & 0.335 & 1.41 & 0.446 & $2.18^{\star *}$ \\
\hline Adj-R-square & $17.87 \%$ & & $26.47 \%$ & & $34.94 \%$ & \\
\hline No. of Observations & 183 & & 198 & & 198 & \\
\hline
\end{tabular}

$* * *$ significance at the 0.01 level, $* *$ significance at the 0.05 level, * significance at the 0.10 level.

The distribution of each variable is truncated at the extreme $\pm 1 \%$ values.

Regression coefficients estimated in calendar time from the Fama-French (1993) three factor regression model:

$\mathrm{R}_{\mathrm{pt}}-\mathrm{R}_{\mathrm{ft}}=\mathrm{a}_{\mathrm{p}}+\mathrm{b}_{\mathrm{p}}\left(\mathrm{R}_{\mathrm{mt}}-\mathrm{R}_{\mathrm{ft}}\right)+\mathrm{s}_{\mathrm{p}} \mathrm{SMB}_{\mathrm{t}}+\mathrm{h}_{\mathrm{p}} \mathrm{HML}_{\mathrm{t}}+\varepsilon_{\mathrm{t}}$

where $R_{p t}$ is the equally weighted portfolio returns in calendar month $t ; R_{f t}$ is the 30-day $T$-bill yield in month $t$; $R_{m t}$ is the return on the value weighted CRSP index; $\mathrm{SMB}_{\mathrm{t}}$ is the return on small firms minus the return on large firms; and $\mathrm{HML}_{\mathrm{t}}$ is the return on high book-to-market stocks minus the return on low book-to-market stocks in month $\mathrm{t}$. 